\title{
Iminoaminosulfinates: Synthesis, Crystal Structures, and Rearrangement monitored by Lithium-7 Solid-state Nuclear Magnetic Resonance Spectroscopy ${ }^{\dagger}$
}

\author{
Stefanie Freitag, Waclaw Kolodziejski,b Frank Pauer and Dietmar Stalke *a \\ a Institut für Anorganische Chemie der Universität Göttingen, Tammannstrasse 4, D-37077 Göttingen, \\ Germany \\ ${ }^{b}$ Department of Chemistry, University of Cambridge, Lensfield Road, Cambridge CB2 1EW, UK
}

\begin{abstract}
Alkali- and alkaline-earth-metal iminoaminosulfinates have been synthesised and characterized by $X$-ray diffraction and solid-state NMR investigations. The viability of metal-exchange reactions has been demonstrated resulting in a magnesium and a copper( 1 ) derivative. The structural investigations reveal the presence of different structures, which can be classified into four types. Phase transitions between different structural types involving the loss of donor solvent have been observed by solid-state magic angle spinning experiments.
\end{abstract}

\begin{abstract}
Alkali-metal iminoaminosulfinates (sulfinamidinates) are widely used in main-group and transition-metal chemistry ${ }^{1-5}$ because of their favourable solubility in hydrocarbons and their steric requirements similar to those of the cyclopentadienyl ligand. They assume four different structural types. ${ }^{6}$ Most of them are dimers, which differ in the way they associate. According to Fig. 1, these can be classified into a twisted tricyclic structure a with $C_{2}$ symmetry, a ladder or step structure b, and an eight-membered ring structure c. The last two types exhibit $C_{i}$ symmetry. Also, the structure of the lithium lithiate $\left[\mathrm{Li}(12 \text {-crown-4 })_{2}\right]^{+}\left[\mathrm{Li}\left\{\left(\mathrm{NSiMe}_{3}\right)_{2} \mathrm{SPh}\right\}_{2}\right]^{-} \quad$ (12-crown-4 = 1,4,7,10-tetraoxacyclododecane) has been reported and classified as of type d. ${ }^{7}$ It consists of a crown ether-complexed lithium cation and an anionic moiety in which lithium is bonded to two chelating iminoaminosulfinate anions, affording an overall singly charged anion of the 'ate' type. ${ }^{8}$
\end{abstract}

Our aim was to obtain compounds with 'tailor-made' reactivity. Thus a series of compounds containing the alkali metals $\mathrm{Li}, \mathrm{Na}, \mathrm{K}, \mathrm{Rb}$ and $\mathrm{Cs}$ was synthesized and structurally characterized ${ }^{6,9}$ (see Table 1). In order to extend this system to alkaline-earth metals and to investigate the viability of metalexchange reactions the compounds $\operatorname{MgBr}\left[\left(\mathrm{Me}_{3} \mathrm{SiN}\right)_{2} \mathrm{SPh}\right]$. thf $\}_{2} 8$ and $\mathrm{Mg}\left[\left(\mathrm{Me}_{3} \mathrm{SiN}\right)_{2} \mathrm{SPh}\right]_{2} \cdot$ thf 9 have now been prepared and structurally characterized. Recently, we investigated the properties of iminoaminosulfinates in alkali-metal derivatives both in the solid state and in solution. In addition, the protonated species $\mathrm{PhS}\left(\mathrm{NHBu}^{t}\right)\left(\mathrm{NSiMe}_{3}\right) \mathbf{1 b}^{6}$ was prepared and structurally characterized. The structure of $\mathrm{PhS}\left(\mathrm{NHSiMe}_{3}\right)$ $\left(\mathrm{NSiMe}_{3}\right) \mathbf{1 a}$ is now reported.

The use of $\mathrm{Bu}^{\mathrm{t}}$ as the substituent on $\mathrm{S}$ has a marked steric influence on the structure. Depending on the $R^{\prime \prime}$ group, there is a transition from an eight-membered ring (type c) to a stairshaped tricycle (type b) in the series $2 \mathbf{b}, \mathbf{2 a}, \mathbf{2 c}$ (described here) where $\mathrm{R}^{\prime \prime}=\mathrm{Bu}^{\mathrm{t}}, \mathrm{SiMe}_{3}$ and $\mathrm{C}_{6} \mathrm{H}_{11}$, respectively, of decreasing steric demands. In all these cases, no $\mathrm{Et}_{2} \mathrm{O}$ molecule bonds to lithium, although the syntheses were carried out in this solvent. Four instances of type a are present in Table 1. The crystal structures of two, $3 c$ and $\mathbf{4 b}$, and NMR investigations on 3a and $3 c$ are reported in this paper. The influence of $R^{\prime \prime}$ on the

† Supplementary data available: see Instructions for Authors, J. Chem. Soc., Dalton Trans., 1993, Issue 1, pp. xxiii-xxviii.

Non-SI unit employed: bar $=10^{5} \mathrm{~Pa}$.

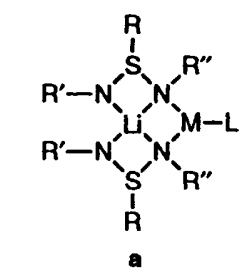

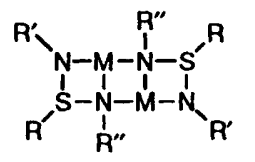<smiles>[R]N([R])[M]N([R])[SH]([R])N([R])[R]</smiles>

c

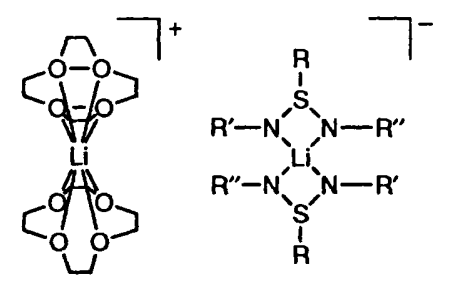

d
Fig. 1 Structural types of iminoaminosulfinates; $M=$ metal, $L=$ donor ligand

structure of series $\mathbf{3 a - 3} \mathbf{c}$ is less dramatic than in $\mathbf{2 a - 2} \mathbf{c}$ (see Tables 3 and 4).

Solid-state NMR experiments provide the opportunity to observe dynamic processes. For the lithium lithiate 3e (type d) three different signals in the solid-state NMR spectrum were detected and assigned for the first time. ${ }^{7}$ Here we present the results of solid-state NMR investigations on the lithiumiminoaminosulfinates $\mathbf{3 a}$ and $\mathbf{3 c}$.

For the lithium to the caesium derivatives, the following trends have been previously identified: ${ }^{6}$ the stair angle between the central $\mathrm{M}_{2} \mathrm{~N}_{2}$ and the peripheral $\mathrm{SN}_{2} \mathrm{M}$ ring planes becomes more acute; the phenyl ring turns towards the metal atom of the other monomeric unit, as can be seen from the torsion angle $\mathrm{N}(1)-\mathrm{S}(1)-\mathrm{C}(1)-\mathrm{C}(6)$ [Fig. $2(b)$ ]; in the series $3 \mathrm{~d}$ $(\mathrm{M}=\mathrm{Li}), 4 \mathrm{a}(\mathrm{Na}), 5 \mathrm{a}(\mathrm{K}), 6(\mathrm{Rb}), 7(\mathrm{Cs})$. For the $\mathrm{M}-\mathrm{N}$ distances the $M(1)-N(2 a)$ distance increases more than the average, which enables the metal to move from the ipso-carbon atom to the ring centre [Fig. 2(a)].

\section{Results and Discussion}

The dimers $3 \mathbf{a},{ }^{6} \mathbf{3 c}$, and $2 \mathbf{c}$ have been prepared by the reactions (1) and (2). All products are obtained in both high yield and 
$2 \mathrm{R}^{\prime \prime}-\mathrm{N}=\mathrm{S}=\mathrm{N}-\mathrm{SiMe}_{3}+2 \mathrm{LiPh} \stackrel{\mathrm{Et}_{2} \mathrm{O}}{\longrightarrow}$

$\left\{\mathrm{Li}\left[\left(\mathrm{R}^{\prime \prime} \mathrm{N}\right)\left(\mathrm{SiMe}_{3} \mathrm{~N}\right) \mathrm{SPh}\right]\right\}_{2} \cdot \mathrm{Et}_{2} \mathrm{O}$

$$
\begin{aligned}
& 3 a R^{\prime \prime}=\operatorname{SiMe}_{3} \\
& \text { 3c } R^{\prime \prime}=\mathrm{C}_{6} \mathrm{H}_{11}
\end{aligned}
$$

$2 \mathrm{C}_{6} \mathrm{H}_{11}-\mathrm{N}=\mathrm{S}=\mathrm{N}-\mathrm{SiMe}_{3}+2 \mathrm{LiBu}^{\mathrm{t}} \longrightarrow$

$$
\left\{\mathrm{Li}\left[\left(\mathrm{C}_{6} \mathrm{H}_{11} \mathrm{~N}\right)\left(\mathrm{SiMe}_{\mathbf{3}} \mathrm{N}\right) \mathrm{SBu}^{\mathrm{t}}\right]\right\}_{2}
$$

purity. The reaction of $1 \mathrm{a}$ and half an equivalent of $3 \mathrm{a}$ with $\mathrm{NaH}$ in 1,2-dimethoxyethane (dme) leads to the formation of the mixed-metal iminoaminosulfinate $4 b$ [equation (3)]. Deproton-

$2 \mathrm{PhS}\left(\mathrm{NHSiMe}_{3}\right)\left(\mathrm{NSiMe}_{3}\right)+\left\{\mathrm{Li}\left[\left(\mathrm{NSiMe}_{3}\right)_{2} \mathrm{SPh}_{3}\right\}_{2} \cdot \mathrm{Et}_{2} \mathrm{O}+\right.$ $2 \mathrm{NaH} \stackrel{\text { dme, }-\mathrm{Et}_{2} \mathrm{O},-\mathrm{H}_{2}}{\longrightarrow} 2 \mathrm{LiNa}\left[\left(\mathrm{SiMe}_{3} \mathrm{~N}\right)_{2} \mathrm{SPh}\right]_{2} \cdot \mathrm{dme}$

$4 \mathbf{b}$

\begin{tabular}{|c|c|c|c|c|c|}
\hline $\begin{array}{l}\text { Com- } \\
\text { pound }\end{array}$ & $\mathbf{M}$ & $\mathbf{R}$ & $\mathbf{R}^{\prime \prime}$ & $\begin{array}{l}\text { Donor } \\
\text { L }\end{array}$ & $\begin{array}{l}\text { Structural } \\
\text { type }\end{array}$ \\
\hline $2 \mathbf{a}$ & $\mathbf{L i}$ & $\mathrm{Bu}^{\mathbf{t}}$ & $\mathrm{SiMe}_{3}$ & - & b \\
\hline $\mathbf{2 b}$ & $\mathrm{Li}$ & $\mathrm{Bu}^{\mathrm{t}}$ & $\mathbf{B} \mathbf{u}^{\mathbf{l}}$ & - & c \\
\hline $2 c$ & $\mathbf{L i}$ & $\mathrm{Bu}^{\prime}$ & $\mathrm{C}_{6} \mathrm{H}_{11}$ & - & b \\
\hline $3 \mathbf{a}$ & $\mathbf{L i}$ & $\mathrm{Ph}$ & $\mathrm{SiMe}_{3}$ & $\mathrm{Et}_{2} \mathrm{O}$ & $\mathbf{a}$ \\
\hline 3b & $\mathbf{L i}$ & $\mathrm{Ph}$ & $\mathrm{Bu}^{\mathrm{t}}$ & $\mathrm{Et}_{2} \mathrm{O}$ & $\mathbf{a}$ \\
\hline $3 \mathbf{c}$ & $\mathrm{Li}$ & $\mathrm{Ph}$ & $\mathrm{C}_{6} \mathrm{H}_{11}$ & $\mathrm{Et}_{2} \mathrm{O}$ & $\mathbf{a}$ \\
\hline 3d & $\mathrm{Li}$ & $\mathrm{Ph}$ & $\mathrm{SiMe}_{3}$ & thf & b \\
\hline $3 e$ & $\mathrm{Li}$ & $\mathrm{Ph}$ & $\mathrm{SiMe}_{3}$ & 12-crown-4 & d \\
\hline $4 \mathbf{a}$ & $\mathrm{Na}$ & $\mathrm{Ph}$ & $B u^{t}$ & thf & b \\
\hline $4 b$ & $\mathrm{Li} / \mathrm{Na}$ & $\mathrm{Ph}$ & $\mathrm{SiMe}_{3}$ & dme & $\mathbf{a}$ \\
\hline $5 \mathbf{a}$ & $\mathbf{K}$ & $\mathrm{Ph}$ & $\mathrm{Bu}^{\mathrm{t}}$ & thf & b \\
\hline $5 \mathbf{b}$ & $\mathbf{K}$ & $\mathrm{Ph}$ & $\mathrm{SiMe}_{3}$ & dme & b \\
\hline 6 & $\mathrm{Rb}$ & $\mathrm{Ph}$ & $\mathrm{SiMe}_{3}$ & thf & b \\
\hline 7 & Cs & $\mathrm{Ph}$ & $\mathrm{SiMe}_{3}$ & thf & b \\
\hline
\end{tabular}

Table 1 Alkali-metal iminoaminosulfinates; $\mathrm{R}^{\prime}=\mathrm{SiMe}_{3}$ in all compounds<smiles>[R]N1[M]N([R])N1[R]</smiles>

thf $=$ Tetrahydrofuran, dme $=1,2$-dimethoxyethane.

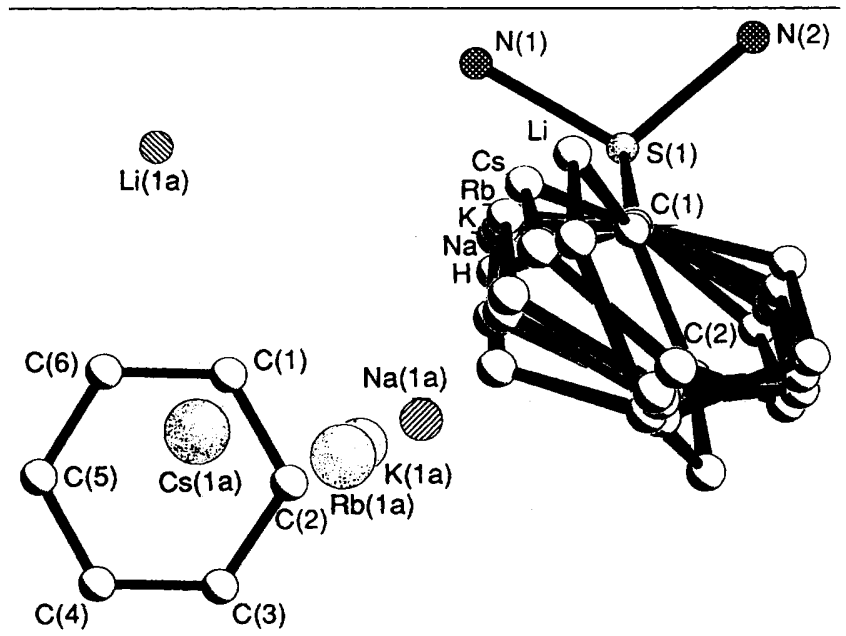

(a)

(b)

Fig. 2 The bonding of the phenyl ring to the metal atom in compounds 3d, 4a, 5a, 6 and 7 (including the position of the phenyl ring in $1 \mathrm{~b}$ ) ation of $1 \mathrm{a}$ with $\mathrm{KH}$ in hexane-dme leads to the product $5 \mathrm{~b}$, equation (4). The magnesium compound 8 was obtained in a

$$
\begin{aligned}
& 2 \mathrm{PhS}\left(\mathrm{NHSiMe}_{3}\right)\left(\mathrm{NSiMe}_{3}\right)+2 \mathrm{KH} \stackrel{\text { dme, }-2 \mathrm{H}_{2}}{\longrightarrow} \\
& \left\{\mathrm{K}\left[\left(\mathrm{NSiMe}_{3}\right)_{2} \mathrm{SPh}\right] \cdot d \mathrm{me}\right\}_{2} \\
& 5 b
\end{aligned}
$$

Grignard reaction with phenylmagnesium bromide and $N, N^{\prime}$ bis(trimethylsilyl)sulfur diimide in thf according to equation (5). ${ }^{3}$ The reaction between 8 and an equimolar amount of $3 a$

$$
2 \mathrm{Me}_{3} \mathrm{Si}-\mathrm{N}=\mathrm{S}=\mathrm{N}-\mathrm{SiMe}_{3}+\underset{\left\{\mathrm{MgBr}\left[\left(\mathrm{SiMe}_{3} \mathrm{~N}\right)_{2} \mathrm{SPh}\right] \cdot \operatorname{thf}\right\}_{2}}{\underset{8}{\operatorname{MgPh}(\mathrm{Br}) \stackrel{\text { thf }}{\longrightarrow}}}
$$

gave 9 with elimination of $\mathrm{LiBr}$ [equation (6)]. Metal exchange

$$
\begin{aligned}
& \left\{\mathrm{MgBr}\left[\left(\mathrm{NSiMe}_{3}\right)_{2} \mathrm{SPh}\right] \cdot \mathrm{thf}\right\}_{2}+ \\
& \left\{\mathrm{Li}\left[\left(\mathrm{NSiMe}_{3}\right)_{2} \mathrm{SPh}\right]\right\}_{2} \cdot \mathrm{Et}_{2} \mathrm{O} \underset{\mathrm{thf},-\mathrm{Et}_{2} \mathrm{O},-2 \mathrm{LiBr}}{2 \mathrm{Mg}\left[\left(\mathrm{SiMe}_{3} \mathrm{~N}\right)_{2} \mathrm{SPh}\right]_{2} \cdot \text { thf }} \\
& \underset{9}{2 \mathrm{M}}
\end{aligned}
$$

involving 3a with $\mathrm{Cu}^{\mathrm{l}} \mathrm{Cl}$ in $\mathrm{Et}_{2} \mathrm{O}$-hexane led to compound 10 [equation (7)], which is slightly sensitive to oxidation and hydrolysis and readily soluble in hydrocarbons.

$$
\begin{aligned}
2\left\{\mathrm{Li}\left[\left(\mathrm{SiMe}_{3} \mathrm{~N}\right)_{2} \mathrm{SPh}\right]\right\}_{2} \cdot \mathrm{Et}_{2} \mathrm{O}+\underset{\mathbf{1 0}}{2 \mathrm{CuCl} \stackrel{-2 \mathrm{LiCl}}{\longrightarrow}} \\
\left\{\mathrm{Cu}\left[\left(\mathrm{NSiMe}_{3}\right)_{2} \mathrm{SPh}\right]\right\}_{2}
\end{aligned}
$$

Solid-state Structures.-Crystallographic data for compounds $1 \mathrm{a}, \mathbf{2 c}, 3 \mathbf{c}, \mathbf{4 b}, 5 \mathbf{b}$ and $8-10$ are listed in Table 2. For the lithium compounds $2 a-2 c$ and $3 a-3 e$ selected structural parameters are presented in Tables 3 and 4, respectively. Atom coordinates are given in Table 5.

Compound 1a.The structure of $\mathrm{PhS}\left(\mathrm{NHSiMe}_{3}\right)\left(\mathrm{NSiMe}_{3}\right)$ 1a (Fig. 3) is very similar to that of $\mathrm{PhS}\left(\mathrm{NHBu}^{\prime}\right)\left(\mathrm{NSiMe}_{3}\right) \mathbf{1 b}^{6}$ The $\mathrm{S}-\mathrm{N}$ bonds differ by $9 \mathrm{pm}$. The $\mathrm{N}(2)$ nitrogen atom forms a single bond $[166.2(1) \mathrm{pm}]$ to the sulfur atom. The distance between $S(1)$ and $N(1)[157.2(1) \mathrm{pm}]$ is not quite consistent with a double bond. ${ }^{10}$ In $\mathrm{I}-\mathrm{N}=\mathrm{S}=\mathrm{N}-\mathrm{I}$ the $\mathrm{S}-\mathrm{N}$ bonds range from $153(1)$ to $160(2) \mathrm{pm}^{11}$ Whereas in $1 \mathrm{a}$ the geometry of $\mathrm{N}(2)$ is nearly planar, the nitrogen atom in $1 \mathrm{~b}$ has a pyramidal environment [deviation of $N(2)$ from the plane of the neighbouring atoms: 7.3 in 1a, $31.5 \mathrm{pm}$ in 1b]. Weak hydrogen bridging between $\mathrm{H}(2 \mathrm{n})$ and $\mathrm{N}(1 \mathrm{a})(214.7 \mathrm{pm})$ affords dimeriz-

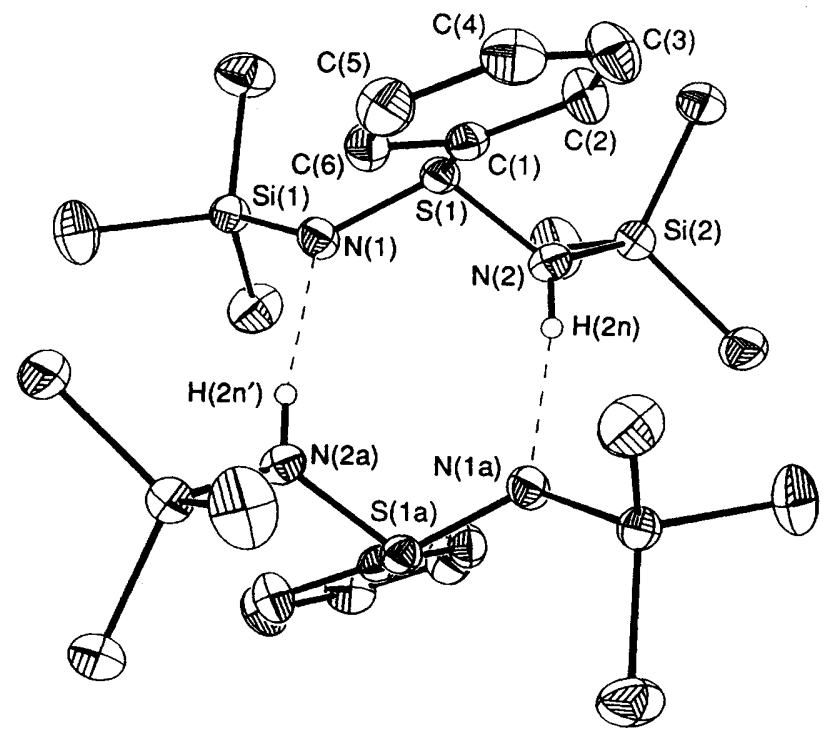

Fig. 3 The dimeric structure of compound $1 \mathrm{a}$ in the solid. Selected distances (pm) and angles $\left({ }^{\circ}\right)$ : $S(1)-N(1)$ 157.2(1); $S(1)-N(2) 166.2(1)$; $\mathrm{S}(1)-\mathrm{C}(1)$ 179.9(2); N(1) ... H(2n') 214.7; N(1)-S(1)-N(2) 112.1(1); $\mathrm{N}(1)-\mathrm{S}(1)-\mathrm{C}(1)$ 104.3(1); N(2)-S(1)-C(1) 99.6(1) 


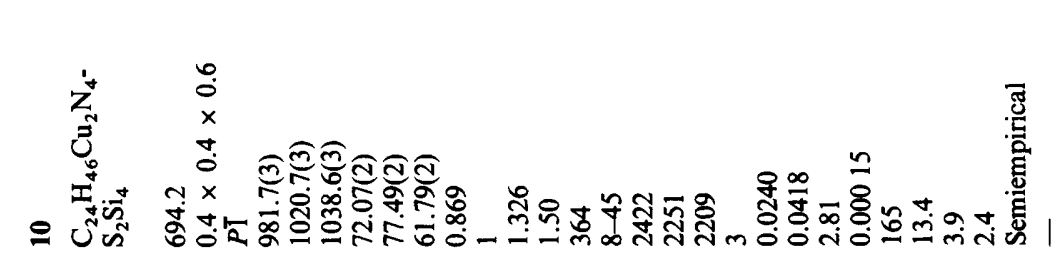

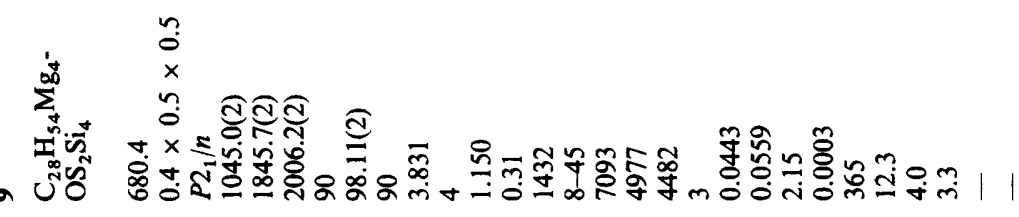

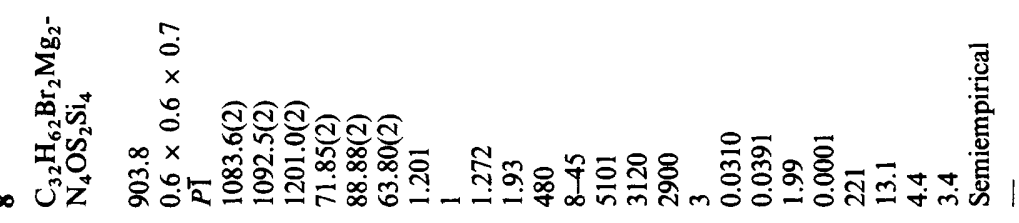

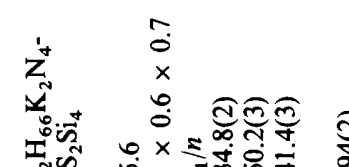

की

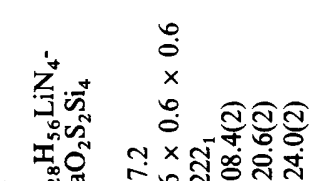

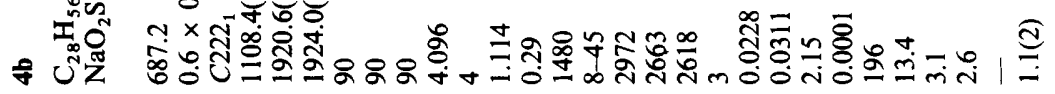

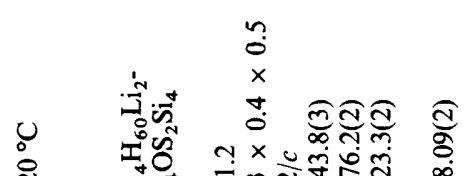

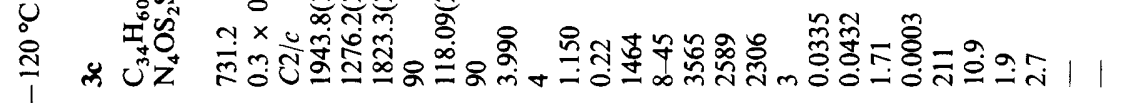

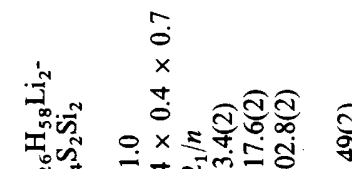

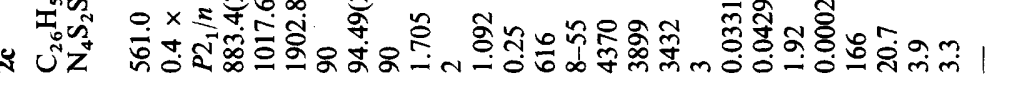

吾

$\dot{4}$
$\dot{0}$
$x$

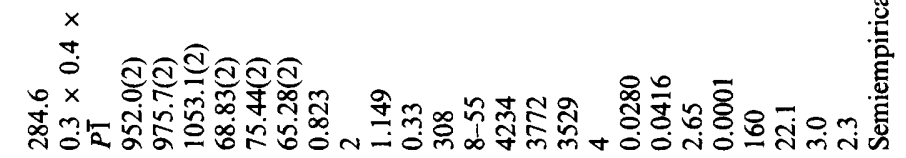

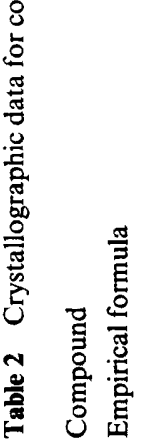

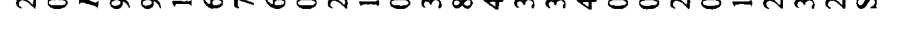

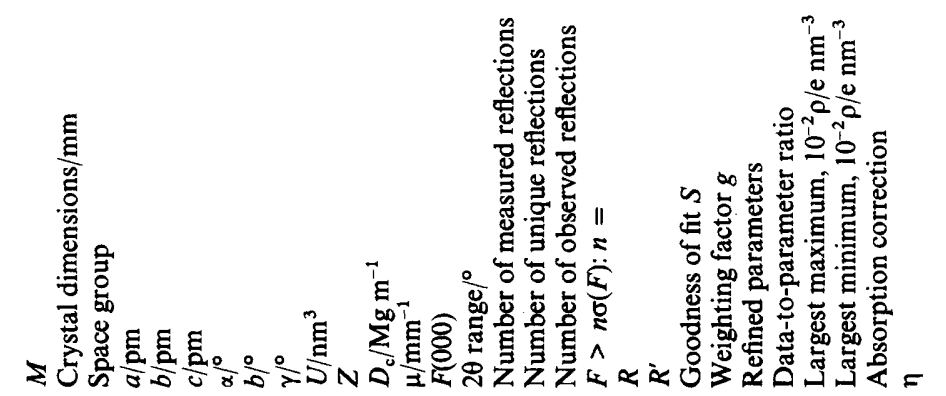


ation (Fig. 3). The corresponding value in $\mathbf{1 b}$ is slightly longer (219.4 pm).

Compound 2c. The transannular $\mathrm{Li}-\mathrm{N}$ distance $[216.9(3) \mathrm{pm}]$ in compound $2 \mathrm{c}$ (Fig. 4) is significantly shorter than in the $\mathrm{N}-\mathrm{SiMe}_{3}$ and $\mathrm{N}-\mathrm{Bu}^{\mathrm{t}}$ derivatives [237.4(8) and 279.6(9) pm, respectively]. Since all three distances are in the range of normal $\mathrm{Li}-\mathrm{N}$ contacts in lithium amides, ${ }^{12} 2 \mathrm{c}$ has to be considered a tricyclic system of three fused four-membered rings (type $b$ ). The stair angle, i.e. that between the $\mathrm{Li}_{2} \mathrm{~N}_{2}$ and $\mathrm{SN}_{2} \mathrm{Li}$ planes, assumes a value of $141.6^{\circ}$, which is close to that of the related compound $3 \mathrm{~d}\left(144.0^{\circ}\right) .^{9}$ In $2 \mathrm{c}$ the environment of both lithium atoms in the dimer is equivalent since they are related by a centre of inversion. They exhibit a trigonal non-planar environment. It is expected that $\mathbf{3 a}-\mathbf{3 c}$ give rise to similar structures after removal of ether molecules, as indicated by the solid-state magic angle spinning (MAS) NMR spectra of 3a and 3c, which show only one environment for the lithium atoms.

Compound 3c. Compounds 3a, ${ }^{9} 3 b^{9}$ and $\left\{\mathrm{Li}\left[\mathrm{PhS}\left(\mathrm{NC}_{6} \mathrm{H}_{11}\right)\right.\right.$ $\left.\left.\left(\mathrm{NSiMe}_{3}\right)\right]\right\}_{2} \cdot \mathrm{Et}_{2} \mathrm{O}$ 3c (Fig. 5) exhibit isotypical a type structures: $\mathrm{Li}(1)$ is bound to all four nitrogen atoms, $\mathrm{Li}(2)$ to the two quaternary nitrogen atoms and the ether molecule. Thus, $3 \mathbf{a}-\mathbf{3 c}$ are rare examples of structures containing lithium atoms in two chemically different environments within the same molecule. ${ }^{13-17}$ They are related to the structure of $\left[\mathrm{Li}\left(\mathrm{NBu}^{\mathrm{t}}\right)\right.$ $\left.\left(\mathrm{OBu}^{\mathrm{t}}\right) \mathrm{SiMe}_{2}\right]_{2} \cdot \mathrm{thf}^{18} \mathrm{In} 3 \mathrm{c}, \mathrm{Li}(1)$ exhibits a fairly short contact to $\mathrm{N}(1)[198.8(2) \mathrm{pm}]$, but the $\mathrm{Li}(1)-\mathrm{N}(2)$ distance $[223.3(4)$

Table 3 Selected bond lengths (pm) and angles $\left({ }^{\circ}\right)$ for compounds $2 \mathrm{a}-2 \mathrm{c}$

$\begin{array}{llll} & \begin{array}{l}\mathbf{2 a}^{a} \\ \left.\mathrm{SiMe}_{3}\right)\end{array} & \begin{array}{l}\mathbf{2 b}^{a} \\ \left(\mathrm{Bu}^{\prime}\right)\end{array} & \begin{array}{l}\mathbf{2 c} \\ \left(\mathrm{C}_{6} \mathrm{H}_{11}\right)\end{array} \\ \mathrm{Li}(1)-\mathrm{N}(1) & 191.6(7) & 190.4(7) & 197.6(3) \\ \mathrm{Li}(1)-\mathrm{N}(2 \mathrm{a}) & 196.5(6) & 191.2(7) & 199.4(3) \\ \mathrm{Li}(1)-\mathrm{N}(2) & 237.4(8) & (279.6)^{b} & 216.9(3) \\ \text { S(1)-N(1) } & 160.5(3) & 160.3(3) & 160.8(1) \\ \text { S(1)-N(2) } & 162.4(3) & 162.5(3) & 163.9(1) \\ \text { S(1)-C(1) } & 185.4(3) & 186.5(3) & 185.7(1) \\ \text { N(1)-Li(1)-N(2a) } & 140.6(4) & 149.1(4) & 143.3(1) \\ \text { N(1)-S(1)-N(2) } & 105.7(1) & 107.1(1) & 105.0(1) \\ \text { N(1)-S(1)-C(1) } & 104.1(1) & 104.1(1) & 104.2(1) \\ \text { N(2)-S(1)-C(1) } & 103.4(1) & 102.0(2) & 104.2(1) \\ \text { C(1)-NSN }{ }^{c} & 113.5 & 112.4 & 113.8 \\ \text { NSNLi-NLiNLi }{ }^{d} & 137.5 & - & 141.6 \\ \text { Ref. } & 6 & 6 & \text { This work }\end{array}$

a Average values of three independent molecules; estimated standard deviations (e.s.d.s) reflect the extreme values. ${ }^{b}$ Non-bonded distance. 'Angle between the $\mathrm{S}(1)-\mathrm{C}(1)$ vector and the plane defined by $\mathrm{N}(1)-\mathrm{S}(1)-\mathrm{N}(2)$. ${ }^{d}$ Angle between the four-membered ring units $\mathrm{Li}(1)-\mathrm{N}(1)-\mathrm{S}(1)-\mathrm{N}(2)$ and $\mathrm{Li}(1)-\mathrm{N}(2)-\mathrm{Li}(1 \mathrm{a})-\mathrm{N}(2 \mathrm{a})$. $\mathrm{pm}]$ is rather long due to the additional bonding of $\mathrm{N}(2)$ to $\mathrm{Li}(2)$ [201.0(3) pm]. The average $\mathrm{S}-\mathrm{N}$ distance in $3 \mathrm{c}$ is $161.7 \mathrm{pm}, 7.1$ pm longer than the $\mathrm{S}=\mathrm{N}$ double bond in $\mathrm{S}\left(\mathrm{NSiMe}_{3}\right)_{2} \cdot{ }^{10} \mathrm{As}$ in $3 \mathrm{a}$, the alkyl substituent is bonded to the quaternary nitrogen. This feature is all the more remarkable in the $\mathrm{NBu}^{t}$ derivative

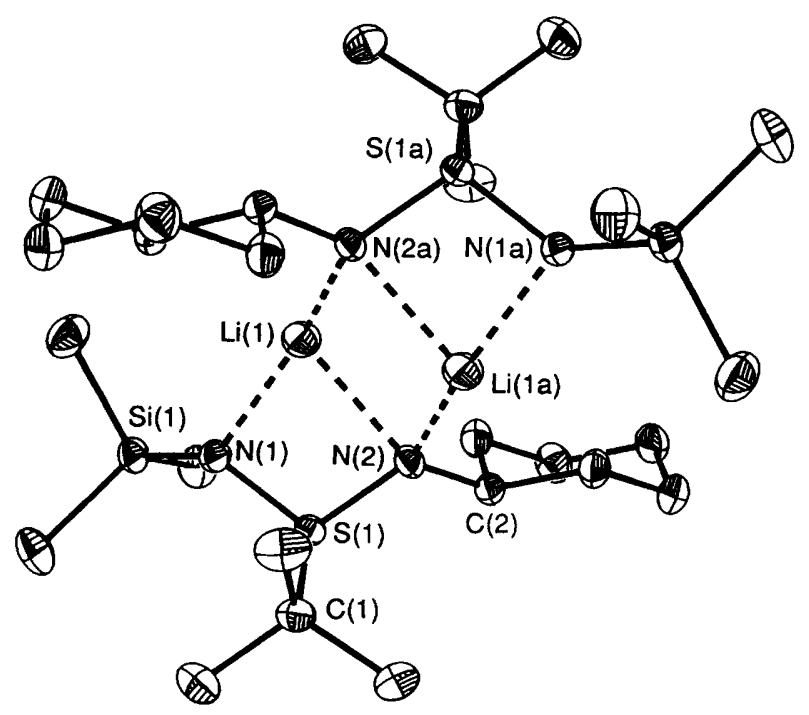

Fig. 4 Crystal structure of compound $2 \mathbf{c}$

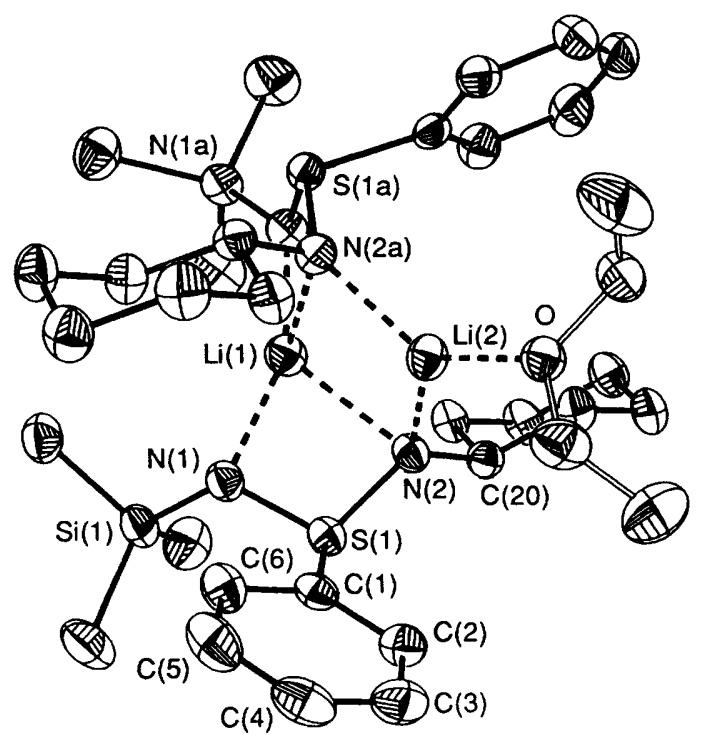

Fig. 5 Crystal structure of compound $3 \mathbf{c}$

Table 4 Selected bond lengths (pm) and angles $\left({ }^{\circ}\right)$ for compounds $3 \mathrm{a}-3 \mathrm{e}$ and $4 \mathrm{~b}$

\begin{tabular}{|c|c|c|c|c|c|c|}
\hline & $\begin{aligned} & \mathbf{3 a} \\
= & \left.\mathrm{SiMe}_{3}\right)\end{aligned}$ & $\begin{array}{l}\text { 3b } \\
\left(\mathrm{Bu}^{\mathrm{t}}\right)\end{array}$ & $\begin{array}{l}3 \mathbf{c} \\
\left(\mathrm{C}_{6} \mathrm{H}_{11}\right)\end{array}$ & $\begin{array}{l}\text { 3d } \\
\left(\mathrm{SiMe}_{3}\right)\end{array}$ & $\begin{array}{l}\mathbf{3 e} \\
\left(\mathrm{SiMe}_{3}\right)\end{array}$ & $\begin{array}{l}\mathbf{4 b} \\
\left(\mathrm{SiMe}_{3}\right)\end{array}$ \\
\hline $\operatorname{Li}(1)-N(1)$ & $199.4(3)$ & $198.3(8)$ & 198.8(2) & $202.2(5)$ & $212.5(8)^{a}$ & $199.4(2)$ \\
\hline $\mathrm{Li}(1)-\mathrm{N}(2)$ & $224.5(5)$ & $223.4(13)$ & $223.3(4)$ & $239.3(5)$ & - & $218.8(3)$ \\
\hline $\mathrm{Li}(1)-\mathrm{N}(2 \mathrm{a})$ & - & - & - & $205.4(5)$ & - & - \\
\hline $\mathrm{Li}(2)\left[\mathrm{Na}(1)^{b}\right]-\mathrm{N}(2)$ & 203.3(5) & $200.5(11)$ & $201.0(3)$ & - & - & $241.7(2)$ \\
\hline $\mathrm{Li}(1)-\mathrm{O}(1)$ & - & - & - & $197.4(5)$ & - & - \\
\hline $\mathrm{Li}(2)\left[\mathrm{Na}(1)^{b}\right]-\mathrm{O}(1)$ & $189.7(9)$ & 192.1(19) & 194.1(5) & - & $235.9(9)^{a}$ & $236.9(2)$ \\
\hline $\mathbf{S}(1)-\mathbf{N}(1)$ & $159.5(3)$ & $161.3(6)$ & $160.7(2)$ & $159.3(2)$ & $160.1(4)^{a}$ & $160.0(2)$ \\
\hline $\mathrm{S}(1)-\mathrm{N}(2)$ & $162.3(3)$ & $162.2(6)$ & $162.7(2)$ & $162.7(2)$ & - & $162.2(2)$ \\
\hline$S(1)-C$ & $180.8(4)$ & $182.6(8)$ & $180.6(2)$ & $180.3(3)$ & $182.0(5)^{a}$ & $181.4(2)$ \\
\hline $\mathrm{N}(1)-\mathrm{S}(1)-\mathrm{N}(2)$ & $105.7(1)$ & $105.6(3)$ & $106.8(1)$ & $105.9(1)$ & $104.4(2)^{a}$ & 104.2(1) \\
\hline$N(1)-S(1)-C$ & $104.4(2)$ & 104.1(3) & 103.9(1) & $104.7(1)$ & $103.4(2)^{a}$ & $104.5(1)$ \\
\hline$N(2)-S(1)-C$ & $101.5(3)$ & $101.5(3)$ & $101.6(1)$ & $104.0(1)$ & - & $102.2(1)$ \\
\hline Ref. & 9 & 9 & This work & 9 & 7 & This work \\
\hline
\end{tabular}

${ }^{a}$ Average value of chemically equivalent parameters. ${ }^{b}$ In $\mathbf{4 b}$, the sodium atom $\mathrm{Na}(1)$ formally replaces $\mathrm{Li}(2)$ in $3 \mathrm{a}-\mathbf{3 c}$. 
considering that the bulky tert-butyl group is located in the sterically more congested area.

Compound 4b. Only a few mixed alkali-metal compounds have been reported. We synthesised the derivative $\mathrm{LiNa}[(\mathrm{Si}$ $\left.\left.\mathrm{Me}_{3} \mathrm{~N}\right)_{2} \mathrm{SPh}\right] \cdot d m e$ $4 \mathrm{~b}$ to investigate the influence of a second metal on the bonding properties of the iminoaminosulfinate and obtain a selective and stepwise reactivity of alkali-metal iminoaminosulfinates. Compound 4b (Fig. 6) exhibits the structural type a and, thus, resembles $3 \mathbf{a}$ and $3 \mathbf{c}$. Formally, $\operatorname{Li}(2)$ in $\mathbf{3 a}$ and $\mathbf{3 c}$ has been replaced by a sodium atom, and dme takes the place of the $\mathrm{Et}_{2} \mathrm{O}$ molecule. These replacements have little influence on the $\mathrm{Li}-\mathrm{N}$ distances $[\mathrm{Li}-\mathrm{N}(1) 199.4(2), \mathrm{Li}-\mathrm{N}(2)$ $218.8(3) \mathrm{pm}$; the corresponding values in 3a are 199.4(3) and $224.5(5) \mathrm{pm}$, respectively]. The $\mathrm{Na}-\mathrm{N}$ bond is $241.7(2) \mathrm{pm}$ and, thus, in the normal $\mathrm{Na}-\mathrm{N}$ range. ${ }^{19}$ Both $\mathrm{SN}_{2} \mathrm{Li}$ four-membered rings form an angle of $134.3^{\circ}$ with the plane of the central $\mathrm{N}_{2} \mathrm{LiNa}$ ring. The corresponding angle in $3 \mathrm{c}$ is only $120^{\circ}$. This angle is widened in $\mathbf{4 b}$ because of the larger sodium atom and the increased steric demand of the donor molecule.

Compound $\mathbf{5 b}$. Despite the increase in the co-ordination number of potassium in $\left\{\mathrm{K}\left[\left(\mathrm{SiMe}_{3} \mathrm{~N}\right)_{2} \mathrm{SPh}\right] \cdot \mathrm{dme}\right\}_{2} \mathbf{5 b}$ with respect to $\left\{\mathrm{K}\left[\left(\mathrm{Bu}^{t} \mathrm{~N}\right)\left(\mathrm{SiMe}_{3} \mathrm{~N}\right) \mathrm{SPh}\right] \cdot\right.$ thf ${ }_{2}{ }_{2} \mathrm{a}^{6}{ }^{6}$ due to the use of a bidentate donor molecule there are only minor changes in the overall structure. Unlike $\mathbf{4 b}, \mathbf{5 b}$ (Fig. 7) adopts a type b structure in the solid. The $\mathrm{K}(1)-\mathrm{N}(2)$ contact is longer $[305.4(2) \mathrm{pm}]$ than in $5 \mathrm{a}[288.0(2) \mathrm{pm}]$, whereas the $\mathrm{K}(1)-\mathrm{N}(1)[272.5(2) \mathrm{pm}]$ and $\mathrm{K}(1)-\mathrm{N}(2 \mathrm{a})[282.3(2) \mathrm{pm}]$ distances are even slightly shorter than in the thf adduct [275.2(3) and $288.0(2) \mathrm{pm}$, respectively]. ${ }^{6}$ Presumably owing to the higher co-ordination number, the potassium-dme contacts [320.3(2) and $288.5(2) \mathrm{pm}]$ are also longer than the $\mathrm{K}(1)-\mathrm{O}_{\mathrm{thf}}$ distance $[271.6(3) \mathrm{pm}]$ in 5a. A similar trend can be observed for the potassium-phenyl interaction ( 376.9 vs. $369.8 \mathrm{pm}$ ).

Compounds 8 and 9. For $\left\{\operatorname{MgBr}\left[\left(\mathrm{Bu}^{t} \mathrm{~N}\right) \mathrm{SBu}^{\mathrm{t}}\right]\right\}_{2}$ and similar compounds a dimeric structure with a central eight-membered ring was proposed. ${ }^{3}$ The crystal structure of $\{\mathrm{MgBr}[(\mathrm{Si}-$ $\left.\mathrm{Me}_{3} \mathrm{~N}\right)_{2} \mathrm{SPh}$-thf $\}_{2} 8$ reveals a dimer (Fig. 8). The monomeric units are bridged by slightly asymmetric $\mathrm{Mg}-\mathrm{Br}$ contacts [256.7(1) and 268.1(1) pm], forming a central four-membered $\mathrm{Mg}_{2} \mathrm{Br}_{2}$ ring. Thus, the structure is different from the ring structure proposed by Kuyper and Vrieze ${ }^{3}$ and that of the alkali-metal derivatives, where oligomerization occurs through metal-nitrogen contacts, and represents a new structural type in this class of compounds. The $\mathrm{Mg}-\mathrm{Br}$ distances are in the range of those for compounds with comparable arrangements. ${ }^{20,21}$

Taking into account the donor thf molecule, the magnesium atoms are five-co-ordinated. The reaction of compound 8 with an equimolar amount of $3 \mathrm{a}^{9}$ affords 9 , which is a monomer in

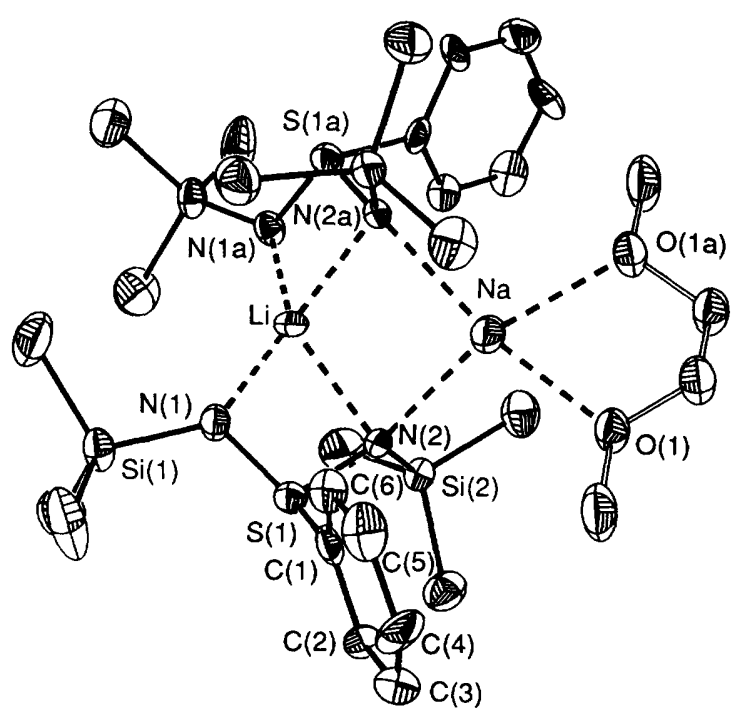

Fig. 6 Crystal structure of compound $4 b$ the solid state (Fig. 9). Oligomerization is precluded by the fiveco-ordination of the central magnesium atom, which involves all four nitrogen atoms of the two iminoaminosulfinate anions and a thf molecule. A structure of this type, with a donorfree, four-co-ordinate magnesium atom and two chelating monoanionic alkoxysilylamide ligands, was proposed for $\left[\mathrm{Mg}\left\{\left(\mathrm{NBu}^{\prime}\right)\left(\mathrm{OBu}^{\prime}\right) \mathrm{SiMe}_{2}\right\}_{2}\right]$ by Veith and Rösler. ${ }^{22}$ These structures are somewhat reminiscent of the situation in the anion in $\left[\mathrm{Li}\left(12 \text {-crown-4) }{ }_{2}\right]^{+}\left[\mathrm{Li}\left\{\left(\mathrm{SiMe}_{3} \mathrm{~N}\right)_{2} \mathrm{SPh}\right\}_{2}\right]^{-} 3 \mathbf{e}{ }^{7}\right.$

The $\mathrm{Mg}-\mathrm{N}$ distances in compound 9 (average $214.2 \mathrm{pm}$ ) are ca. $5 \mathrm{pm}$ longer than in 8 (average $209.2 \mathrm{pm}$ ), presumably due to the electrostatic repulsion between the anions. They are bonded to the same cation in the case of 9 , whereas in 8 they are separated by a $\mathrm{Mg}_{2} \mathrm{Br}_{2}$ four-membered ring. Likewise, the $\mathrm{Mg}-\mathrm{O}$ distances differ by a similar amount ( $\mathrm{ca} .6 \mathrm{pm}$ ). In both 8 and 9 the two $\mathrm{S}-\mathrm{N}$ bond lengths in the same anion differ less $\left(1.3 \mathrm{pm}\right.$ in 8,0.6 pm in 9) than in the alkali-metal derivatives, ${ }^{6,9}$ presumably owing to the nitrogen atoms having the same coordination number.

Whereas the alkali-metal derivatives exhibit $\mathrm{N}-\mathrm{S}-\mathrm{N}$ bond angles between 104.2 and $110.7^{\circ}, 6$ the corresponding values in compounds $8\left[98.5(1)^{\circ}\right]$ and $9\left[100.1(1)^{\circ}\right]$ are significantly smaller. This can be attributed to the higher charge on $\mathrm{Mg}^{2+}$. Thus, the electrostatic repulsion between the metal and the

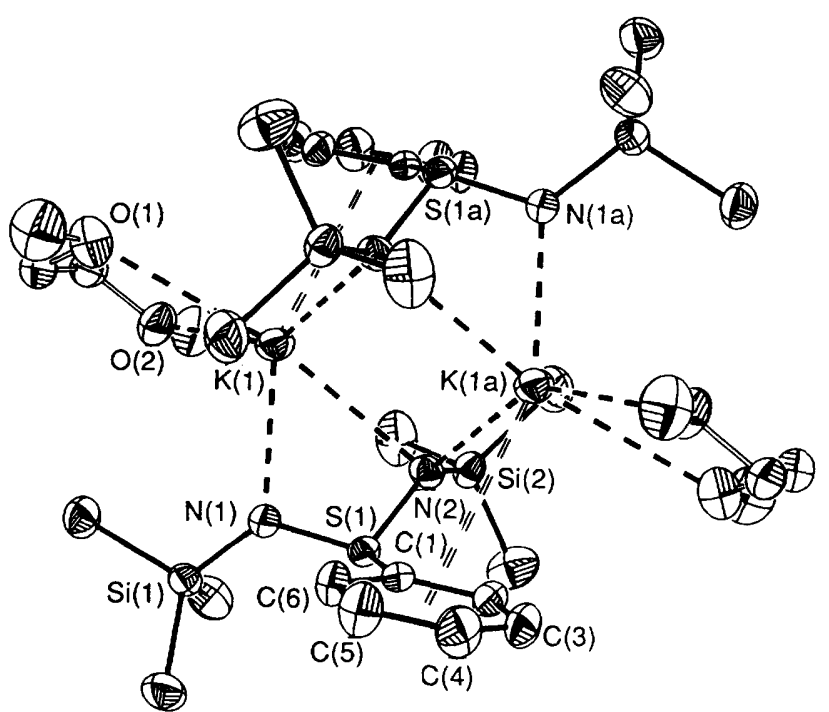

Fig. 7 Crystal structure of compound $5 \mathbf{b}$. Selected distances (pm) and angles $\left({ }^{\circ}\right)$ : $\mathrm{K}(1)-\mathrm{N}(1) 272.5(2), \mathrm{K}(1)-\mathrm{N}(2) 305.4(2), \mathrm{K}(1)-\mathrm{N}(2 \mathrm{a}) 282.3(2)$, $\mathrm{K}(1)-\mathrm{O}(1) 320.3(2), \mathrm{K}(1)-\mathrm{O}(2) 288.5(2), \mathrm{S}(1)-\mathrm{N}(1)$ 159.7(2), S(1)-N(2) 161.1(1), $\mathrm{S}(1)-\mathrm{C}(1) \quad 181.2(2), \mathrm{K}(1)-\mathrm{Ph}_{\text {centre }} \quad 376.9 ; \quad \mathrm{N}(1)-\mathrm{S}(1)-\mathrm{N}(2)$ 110.2(1), N(1)-S(1)-C(1) 102.8(1), N(2)-S(1)-C(1) 100.6(1)

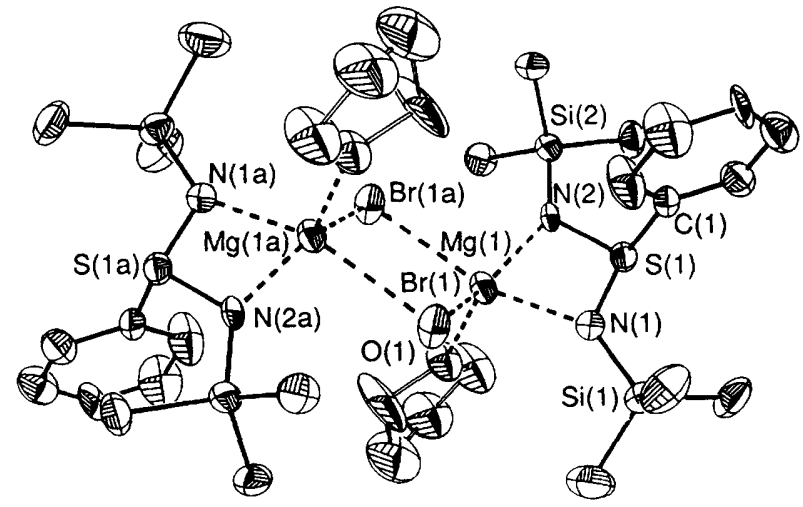

Fig. 8 Crystal structure of compound 8. Selected distances (pm) and angles ( $\left.{ }^{\circ}\right): \mathrm{Mg}(1)-\mathrm{N}(1) 210.6(3), \mathrm{Mg}(1)-\mathrm{N}(2)$ 207.8(2), $\mathrm{Mg}(1)-\mathrm{Br}(1)$ 256.7(1), $\mathrm{Mg}(1)-\mathrm{Br}(1 \mathrm{a}) \quad 268.1(1), \quad \mathrm{Mg}(1)-\mathrm{O}(1)$ 201.4(2), $\mathrm{S}(1)-\mathrm{N}(1)$ $160.3(2), \mathrm{S}(1)-\mathrm{N}(2) 161.6(3) ; \mathrm{N}(1)-\mathrm{Mg}(1)-\mathrm{N}(2) 71.3(1), \mathrm{N}(1)-\mathrm{S}(1)-\mathrm{N}(2)$ $98.5(1)$ 


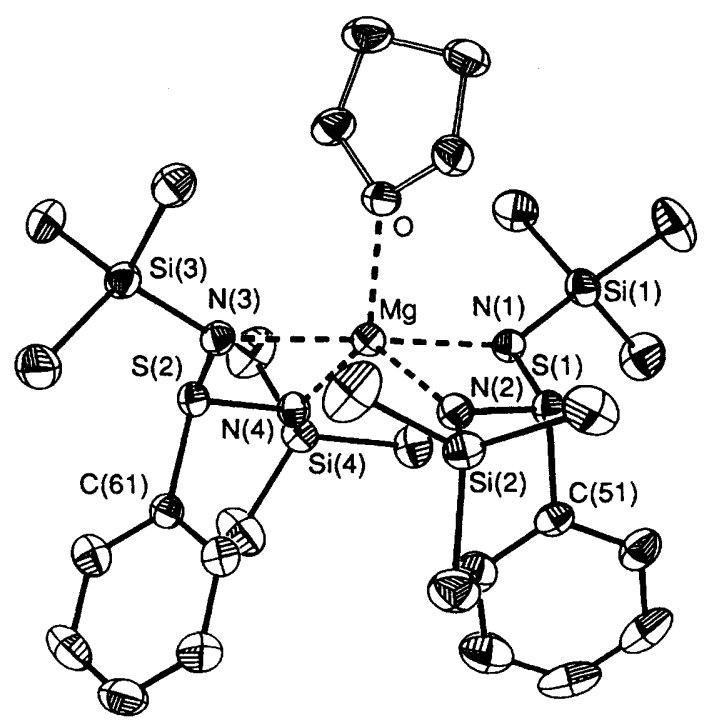

Fig. 9 Crystal structure of compound 9. Selected distances (pm) and angles ('): $\mathrm{Mg}-\mathrm{N}(1)$ 218.9(2), $\mathrm{Mg}-\mathrm{N}(2)$ 209.8(2), $\mathrm{Mg}-\mathrm{N}(3)$ 217.5(2), $\mathrm{Mg}-\mathrm{N}(4) \quad 210.7(2), \mathrm{Mg}-\mathrm{O}$ 207.4(2), $\mathrm{S}(1)-\mathrm{N}(1) 161.1(2), \mathrm{S}(1)-\mathrm{N}(2)$ 161.7(2), S(2)-N(3) 161.4(2), S(2)-N(4) 161.9(2); N(1)-Mg-N(2) 70.5(1), $\mathrm{N}(3)-\mathrm{Mg}-\mathrm{N}(4) \quad 70.7(1), \quad \mathrm{N}(1)-\mathrm{S}(1)-\mathrm{N}(2) \quad 100.1(1), \quad \mathrm{N}(3)-\mathrm{S}(2)-\mathrm{N}(4)$ $100.0(1)$

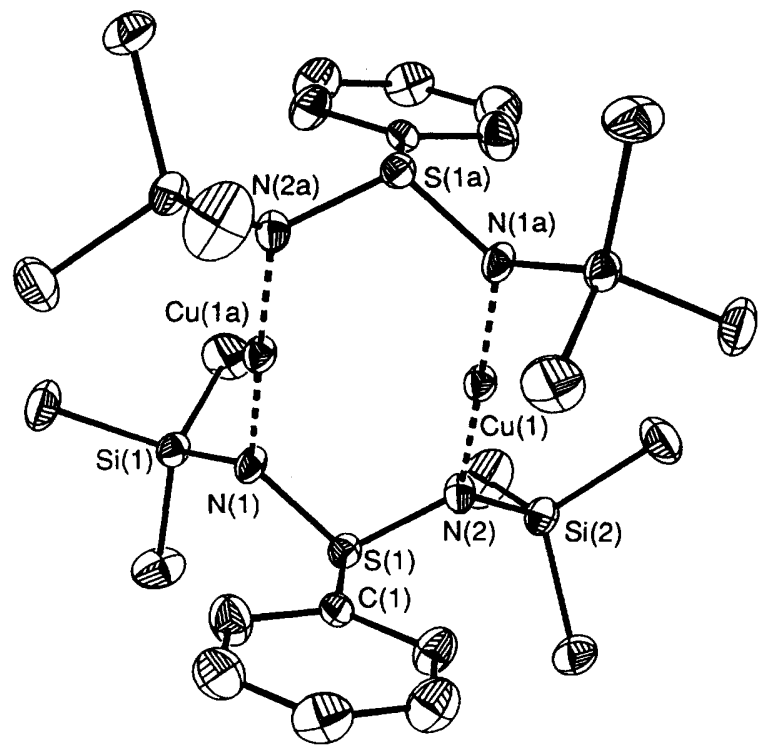

Fig. 10 Crystal structure of compound 10. Selected distances (pm) and angles $\left({ }^{\circ}\right)$ : $\mathrm{Cu}(1)-\mathrm{N}(1)$ 187.3(2), $\mathrm{Cu}(1)-\mathrm{N}(2 \mathrm{a}) 187.4(2) ; \mathrm{Cu}(1) \cdots \mathrm{Cu}(1 \mathrm{a})$ 270.2(1), S(1)-N(1) 161.3(2), S(1)-N(2) 162.5(3), N(1)-Cu(1)-N(2a) 178.6(1), N(1)-S(1)-N(2) 110.4(1)

sulfur atom is higher in the cases of $\mathbf{8}$ and 9 . This observation is in accord with the N-Si-N angle in $\left\{\mathrm{Mg}\left[\left(\mathrm{Bu}^{\mathrm{t}} \mathrm{N}\right)_{2} \mathrm{SiMe}_{2}\right] \cdot \text { thf }\right\}_{2},{ }^{23}$ which is also considerably smaller $\left(99.9^{\circ}\right)$ than in a monoanionic alkoxysilylamide system with alkali metals as counter cations (average $106.5^{\circ}$ ). ${ }^{18,24}$

The reaction of Grignard reagents with the sulfur diimide system leads to structures different from those of the corresponding alkali-metal derivatives. Further investigations of metal-exchange reactions and other alkaline-earth metal iminoaminosulfinates are underway.

Compound 10. The structure of compound 10 in the solid state shows a dimeric, c-type arrangement (Fig. 10). No transannular $\mathrm{Cu}-\mathrm{N}$ contacts are present. The $\mathrm{Cu}$ atoms show a linear environment $\left[\mathrm{N}-\mathrm{Cu}-\mathrm{N} 178.6(1)^{\circ}\right]$ of the symmetrically bonded $\mathrm{N}$ atoms $[\mathrm{Cu}(1)-\mathrm{N}(1)$ 187.3(2), $\mathrm{Cu}(1)-\mathrm{N}(2 \mathrm{a}) 187.4(2) \mathrm{pm}]$. The transannular $\mathrm{Cu} \cdots \mathrm{Cu}$ distance $[270.2(1) \mathrm{pm}]$ is longer than in

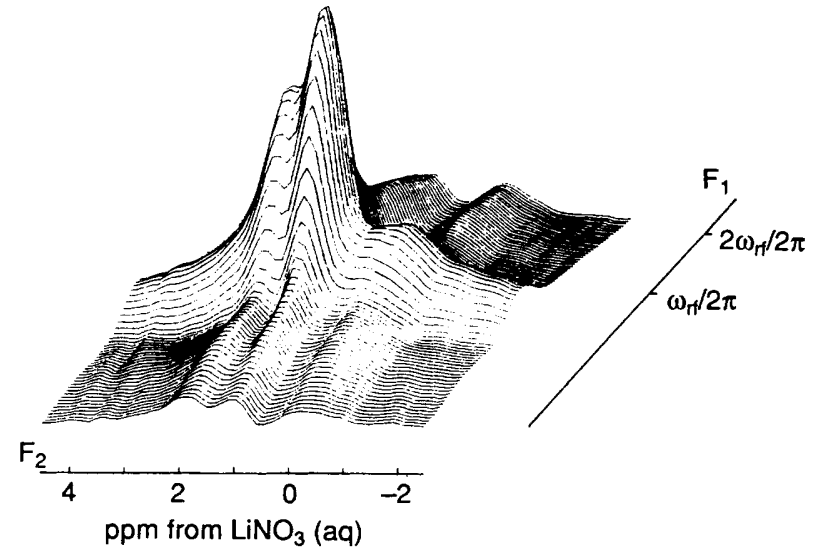

Fig. 11 Lithium-7 quadrupole nutation MAS NMR spectrum of compound $3 \mathbf{c}$

the isotypical copper benzamidinate ${ }^{25}[242.5(2) \mathrm{pm}]$, due to the greater cone angle of the $\mathrm{N}-\mathrm{S}-\mathrm{N}$ system, and is too long to be considered as a metal-metal interaction, as there is in the three-centre two-electron bond in $\left[\mathrm{Li}(\text { thf })_{4}\right]\left[\mathrm{Cu}_{5} \mathrm{Cl}_{4}\right.$ $\left.\left\{\mathrm{Si}\left(\mathrm{SiMe}_{3}\right)_{3}\right\}_{2}\right]$ with a $\mathrm{Cu}-\mathrm{Cu}$ bond of $240.3(2) \mathrm{pm}^{26}$

Solid-state MAS NMR Investigations of Compounds 3a and 3c.-Solution NMR data for $\left\{\mathrm{Li}\left[\left(\mathrm{SiMe}_{3} \mathrm{~N}\right)_{2} \mathrm{SPh}\right]\right\}_{2} \cdot \mathrm{Et}_{2} \mathrm{O} 3 \mathrm{a}$ have been published. ${ }^{9}$ This compound exhibits two signals in the ${ }^{7} \mathrm{Li}$ NMR spectrum in $\mathrm{C}_{7} \mathrm{D}_{8}$ at $-60^{\circ} \mathrm{C}(\delta 1.2,2.7$ in a $1: 1$ ratio). At this temperature two signals for the chemically nonequivalent silyl groups can be resolved in the ${ }^{1} \mathrm{H}$ NMR spectrum. Conversely, the ${ }^{6} \mathrm{Li},{ }^{1} \mathrm{H}$ Heteroatom Overhauser Effect Spectroscopy (HOESY) NMR spectrum of $\left\{\mathrm{Li}\left[\left(\mathrm{Bu}^{t} \mathrm{~N}\right)-\right.\right.$ $\left.\left.\left(\mathrm{SiMe}_{3} \mathrm{~N}\right) \mathrm{SPh}\right]\right\}_{2} \cdot \mathrm{Et}_{2} \mathrm{O} \mathbf{3 b}^{9}$ exhibits exchange of the $\mathrm{Bu}^{1}$ and the $\mathrm{Me}_{3} \mathrm{Si}$ groups even at $-70^{\circ} \mathrm{C}$. Within the NMR time-scale, the chemical shifts for both groups show identical cross-peaks with both ${ }^{6} \mathrm{Li}$ signals.

For $\left[\mathrm{Li}(12 \text {-crown-4) }]^{+}\left[\mathrm{Li}\left\{\left(\mathrm{SiMe}_{3} \mathrm{~N}\right)_{2} \mathrm{SPh}\right\}_{2}\right]^{-} 3 \mathrm{e}\right.$ it was possible for the first time to resolve and assign three different lithium-7 environments in a ${ }^{7} \mathrm{Li}$ MAS NMR experiment. ${ }^{7}$ Solidstate NMR spectroscopy is a versatile physical method by which phase transformations may be investigated. Lithium-7 quadrupole nutation MAS NMR spectroscopy was also applied to $3 \mathrm{c}$ (Fig. 11). The two-dimensional spectrum was recorded with a $91 \pm 5 \mathrm{kHz}$ radiofrequency excitation field, $\omega_{\mathrm{rf}} / 2 \pi, 5 \mathrm{~s}$ recycle delay and $c a .3 .5 \mathrm{kHz}$ spinning rate. The $\mathrm{F}_{2}$ axis of twodimensional NMR spectra consists of a combination of chemical shift and second-order quadrupolar shift, whereas the $F_{1}$ axis includes only quadrupolar information. This method allows lithium-7 environments with different quadrupolar coupling constants $C_{\mathrm{Q}}$ along $\mathrm{F}_{1}$ to be resolved. ${ }^{27}$ Unexpectedly, the spectrum shows three signals instead of two. Owing to their width and partial overlap we refrain from quoting chemical shifts. However, the spectrum clearly shows three ${ }^{7} \mathrm{Li}$ nuclei in different environments.

Removing the clear, colourless crystals of compounds 3a and $3 \mathbf{c}$ from the mother-liquor causes withering and transformation into a yellow amorphous powder, which is insoluble in nonpolar solvents. This transformation had progressed significantly at the time of the experiment depicted in Fig. 11. The two signals of the starting material and that of the transformation product are discernible.

We repeated the solid-state MAS NMR experiment and produced one-dimensional ${ }^{7} \mathrm{Li}$ MAS spectra in order to account for the transformation in detail (Fig. 12). As expected two signals can be seen. A third peak begins to appear after evacuating both samples for $24 \mathrm{~h}$. For compound 3a, after heating to $c a .50^{\circ} \mathrm{C}$ and $10^{-2}$ bar for $10 \mathrm{~min}$, both original signals have disappeared and a new one (b) has formed. When the same experiment was performed on $3 \mathrm{c}$ the original signals 
were still present, but the peak assigned to the transformation product is predominant (d). This experiment clearly indicates that the two different lithium-7 environments in $\mathbf{3 a}$ and $\mathbf{3 c}$ are no longer present in the product. Therefore, there can be only one type of environment for the lithium atom in the product. In our opinion, the ether molecule is released into the gas phase and the dimers have to reorganize (Scheme 1). The bond between one nitrogen atom and the four-co-ordinate lithium atom opens. One anionic monomer rotates around the remaining $\mathrm{Li}-\mathrm{N}$ bonds, and the nitrogen atom attached to the lithium atom from which the ether molecule has been removed. The plausibility of this transformation is supported by the knowledge of the structural type of the product.

\section{Conclusion}

The iminoaminosulfinate anion has proven to be versatile for the steric stabilization of metal derivatives, even in less-stable oxidation states, as exemplified by the copper derivative 10. It enables a favourable solubility in non-polar solvents. In contrast to an analogous series of alkali-metal iminoaminophosphinates, ${ }^{28}$ the class of compounds presented here is structurally homogeneous within the first main-group derivatives. Varying the substituent at one or both nitrogen atoms as well as at the sulfur atom allows excellent fine-tuning of the steric requirement of the sulfinate. Furthermore, it exhibits a variety of structural features and, by virtue of the properties of its substituents, is readily accessible to NMR studies at different temperatures and transition phases. Further investigations of metal-exchange reactions and of pathways leading to anions with 'inorganic' substituents at $\mathrm{S}$ are underway.

\section{Experimental}

All experiments were carried out under dry argon with strict exclusion of air and moisture. Mass spectra: Varian $\mathrm{CH} 5$ spectrometer. NMR: ${ }^{1} \mathrm{H},{ }^{7} \mathrm{Li},{ }^{13} \mathrm{C}, 10 \%$ solutions in $\mathrm{C}_{6} \mathrm{D}_{5} \mathrm{CD}_{3}$ $\left({ }^{1} \mathrm{H}\right.$ of 9 in $\mathrm{C}_{6} \mathrm{D}_{6}, 8$ in $\left.\mathrm{C}_{4} \mathrm{D}_{8} \mathrm{O}\right) ;{ }^{29} \mathrm{Si}, 20 \%$ solutions in $\mathrm{C}_{6} \mathrm{D}_{5} \mathrm{CD}_{3}, \mathrm{SiMe}_{4}, \mathrm{LiCl}$ external, Bruker AM 250 spectrometer.

The compound $\mathrm{PhS}\left(\mathrm{NHSiMe}_{3}\right)\left(\mathrm{NSiMe}_{3}\right)$ 1a was prepared according to literature procedures. ${ }^{6}$

Syntheses.-Compound 2c. The compound $\mathrm{C}_{6} \mathrm{H}_{11}-\mathrm{N}=\mathrm{S}=\mathrm{O}$ was prepared according to literature procedures; ${ }^{29} \mathrm{C}_{6} \mathrm{H}_{11}-$ $\mathrm{N}=\mathrm{S}=\mathrm{N}-\mathrm{SiMe}_{3}$ was prepared analogously to the corresponding $\mathrm{Bu}^{t}$ and Et derivatives. ${ }^{30,31}$ The compound $\mathrm{C}_{6} \mathrm{H}_{11}-\mathrm{N}=\mathrm{S}=\mathrm{N}-$ $\mathrm{SiMe}_{3}(0.01 \mathrm{~mol})$ was dissolved in pentane $\left(50 \mathrm{~cm}^{3}\right)$ and cooled to $-60^{\circ} \mathrm{C}$. tert-Butyllithium $\left(0.01 \mathrm{~mol}, 1.5 \mathrm{~mol} \mathrm{dm}^{-3}\right.$ solution in pentane) and $\mathrm{Et}_{2} \mathrm{O}(0.04 \mathrm{~mol})$ were added dropwise. The reaction mixture was allowed to warm to room temperature and refluxed for $1 \mathrm{~h}$. After $4 \mathrm{~d}$ single crystals of compound $2 \mathrm{c}$ suitable for X-ray analysis were obtained. Yield: $2.4 \mathrm{~g}, 86 \%$ (room temperature): ${ }^{1} \mathrm{H}, \delta 0.27\left(\mathrm{~s}, \mathrm{SiMe}_{3}\right), 0.88-1.73\left(\mathrm{~m}, \mathrm{C}_{6} \mathrm{H}_{11}\right), 1.05$ and $1.07(\mathrm{~s}, \mathrm{SBu}) ;{ }^{7} \mathrm{Li}, \delta 1.7 ;{ }^{13} \mathrm{C}, \delta 3.25,3.36\left[\mathrm{Si}\left(\mathrm{CH}_{3}\right)_{3}\right], 22.93$, $23.29\left[\mathrm{SC}\left(\mathrm{CH}_{3}\right)_{3}\right], 28.14\left[\mathrm{SC}\left(\mathrm{CH}_{3}\right)_{3}\right], 37.24,37.55,39.45$, $55.25,55.70,61.05$ and $61.20\left(\mathrm{C}_{6} \mathrm{H}_{11}\right) ;{ }^{29} \mathrm{Si}, \delta-4.4$.

Compound 3c. The compound $\mathrm{C}_{6} \mathrm{H}_{11}-\mathrm{N}=\mathrm{S}=\mathrm{N}-\mathrm{SiMe}_{3}(0.02$ $\mathrm{mol})$ was dissolved in hexane $\left(50 \mathrm{~cm}^{3}\right)$ and cooled to $-50^{\circ} \mathrm{C}$. A $2 \mathrm{~mol} \mathrm{dm}{ }^{-3}$ solution of $\mathrm{LiPh}\left(10 \mathrm{~cm}^{3}\right)$ in hexane-Et $\mathrm{t}_{2} \mathrm{O}$ was added dropwise. After warming to room temperature, the reaction mixture was refluxed for $1 \mathrm{~h}$. After $2 \mathrm{~d}$ single crystals of compound $3 c$ suitable for X-ray analysis were obtained. Yield: $6.3 \mathrm{~g}, 93 \%$. NMR (room temperature): ${ }^{1} \mathrm{H}, \delta 0.26\left(\mathrm{~s}, \mathrm{SiMe}_{3}\right.$ ), 0.80-1.85 $\left(\mathrm{m}, \mathrm{C}_{6} \mathrm{H}_{11}\right)$ and 6.97-7.80 $\left(\mathrm{m}, \mathrm{C}_{6} \mathrm{H}_{5}\right) ;{ }^{7} \mathrm{Li}, \delta 1.5 ;{ }^{13} \mathrm{C}$, $\delta 2.84\left[\mathrm{Si}\left(\mathrm{CH}_{3}\right)_{3}\right], 15.20\left[\mathrm{O}\left(\mathrm{CH}_{2} \mathrm{CH}_{3}\right)_{2}\right], 37.57,38.85,40.89$, $61.43\left(\mathrm{C}_{6} \mathrm{H}_{11}\right), 65.35\left[\mathrm{O}\left(\mathrm{CH}_{2} \mathrm{CH}_{3}\right)_{2}\right], 126.23,128.41,129.18$ and $146.10\left(\mathrm{C}_{6} \mathrm{H}_{5}\right) ;{ }^{29} \mathrm{Si}, \delta-4.2$.

Compound 4b. The compound $\mathrm{PhS}\left(\mathrm{NHSiMe}_{3}\right)\left(\mathrm{NSiMe}_{3}\right)$ $(0.01 \mathrm{~mol})$ was dissolved in hexane $\left(20 \mathrm{~cm}^{3}\right)$ and added dropwise to a suspension of $\mathrm{NaH}(0.011 \mathrm{~mol})$ and $\left\{\mathrm{Li}\left[\left(\mathrm{SiMe}_{3} \mathrm{~N}\right)_{2} \mathrm{SPh}\right]\right\}_{2}$. $\mathrm{Et}_{2} \mathrm{O}(0.005 \mathrm{~mol})$ in hexane $\left(20 \mathrm{~cm}^{3}\right)$ and dme $(0.04 \mathrm{~mol})$. After (a)

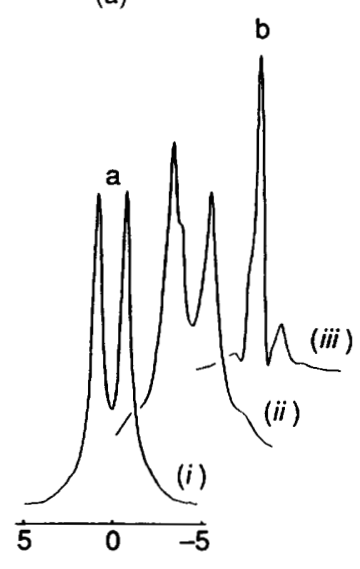

(b)

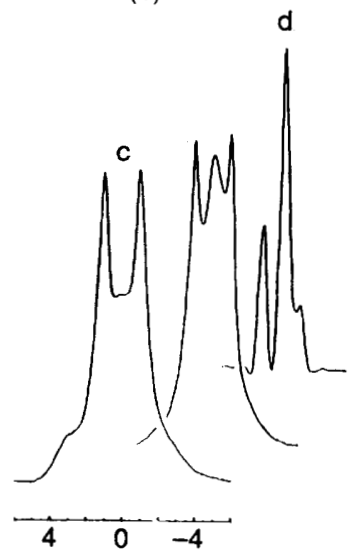

$\delta$
Fig. 12 Solid-state ${ }^{7} \mathrm{Li}$ MAS NMR spectra of compounds 3a $(a)$ and $3 \mathrm{c}(b)$ : (i) sample from mother-liquor; (ii) after $24 \mathrm{~h}$ at $10^{-2} \mathrm{bar}$; (iii) after heating at $10^{-2}$ bar

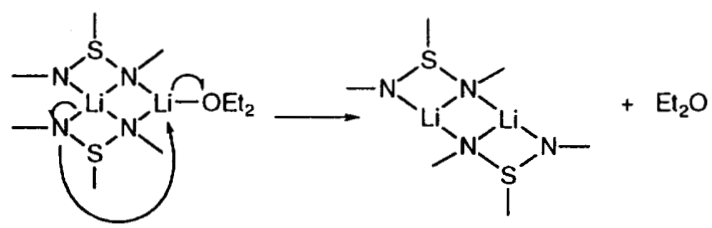

Scheme 1 Reorganization of an a to a b-type structure after release of the donor molecule

cooling the excess of $\mathrm{NaH}$ was filtered off. The solution was kept at $-35^{\circ} \mathrm{C}$ for $10 \mathrm{~d}$ until crystals suitable for X-ray crystallography were obtained. NMR (room temperature): ${ }^{1} \mathbf{H}$, $\delta 0.29\left(\mathrm{~s}, \mathrm{SiMe}_{3}\right), 2.94\left[\mathrm{~s}, \mathrm{CH}_{3} \mathrm{O}\left(\mathrm{CH}_{2}\right)_{2} \mathrm{OCH}_{3}\right], 2.99[\mathrm{~s}$, $\left.\mathrm{CH}_{3} \mathrm{O}\left(\mathrm{CH}_{2}\right)_{2} \mathrm{OCH}_{3}\right]$ and $6.99-7.82\left(\mathrm{~m}, \mathrm{C}_{6} \mathrm{H}_{5}\right) ;{ }^{7} \mathrm{Li}, \delta 1.8$; ${ }^{13} \mathrm{C}, \delta 3.21\left[\mathrm{Si}\left(\mathrm{CH}_{3}\right)_{3}\right.$ ] $58.60,71.17$ (dme), 125.69, 127.88, 128.42 and $159.12\left(\mathrm{C}_{6} \mathrm{H}_{5}\right) ;{ }^{29} \mathrm{Si}, \delta-4.2$.

Compound 5b. The compound $\mathrm{PhS}\left(\mathrm{NHSiMe}_{3}\right)\left(\mathrm{NSiMe}_{3}\right)$ $(0.01 \mathrm{~mol})$ was dissolved in hexane $\left(20 \mathrm{~cm}^{3}\right)$ and added dropwise to a suspension of $\mathrm{KH}(0.011 \mathrm{~mol})$ in hexane $\left(10 \mathrm{~cm}^{3}\right)$ and dme $(0.04 \mathrm{~mol})$. The reaction mixture was refluxed for $2 \mathrm{~h}$. After cooling, the excess of $\mathrm{KH}$ was filtered off. The solution was kept at $-35^{\circ} \mathrm{C}$ for several weeks to grow crystals of compound $\mathbf{5 b}$ suitable for X-ray crystallography. Yield: $3.4 \mathrm{~g}, 83 \%$. NMR (room temperature): ${ }^{1} \mathrm{H}, \delta 0.26\left(\mathrm{~s}, \mathrm{SiMe}_{3}\right), \quad 3.10[\mathrm{~s}$, $\left.\mathrm{CH}_{3} \mathrm{O}\left(\mathrm{CH}_{2}\right)_{2} \mathrm{OCH}_{3}\right]$ and $3.26\left[\mathrm{~s}, \mathrm{CH}_{3} \mathrm{O}\left(\mathrm{CH}_{2}\right)_{2} \mathrm{OCH}_{3}\right]$.

Compound 8. Bromobenzene ( $0.01 \mathrm{~mol})$ was added dropwise to magnesium turnings $(0.01 \mathrm{~mol})$ in $\mathrm{Et}_{2} \mathrm{O}\left(20 \mathrm{~cm}^{3}\right)$. The reaction mixture was refluxed for $1 \mathrm{~h}$, transferred to a dropping funnel, and added to $\mathrm{Me}_{3} \mathrm{Si}-\mathrm{N}=\mathrm{S}=\mathrm{N}-\mathrm{SiMe}_{3}(0.01 \mathrm{~mol})$ in hexane $(50$ $\mathrm{cm}^{3}$ ). Compound 8 was precipitated from the solution and can be dissolved by addition of thf $(1.5 \mathrm{~g})$. Single crystals suitable for $\mathrm{X}$-ray crystallography were obtained from this solution at $-20^{\circ} \mathrm{C}$. Yield: $3.0 \mathrm{~g}, 90 \%$. NMR $\left(\mathrm{C}_{4} \mathrm{D}_{8} \mathrm{O}\right.$, room temperature): ${ }^{1} \mathrm{H}, \delta 0.00\left(\mathrm{~s}, \mathrm{SiMe}_{3}\right), 1.73\left[\mathrm{t}, \mathrm{O}\left(\mathrm{CH}_{2}\right)_{2}\left(\mathrm{CH}_{2}\right)_{2}\right], 3.58[\mathrm{t}$, $\left.\mathrm{O}\left(\mathrm{CH}_{2}\right)_{2}\left(\mathrm{CH}_{2}\right)_{2}\right]$ and $7.10-7.95\left(\mathrm{~m}, \mathrm{C}_{6} \mathrm{H}_{5}\right) ;{ }^{13} \mathrm{C}, \delta 1.98\left(\mathrm{SiMe}_{3}\right)$, $25.26\left[\mathrm{O}\left(\mathrm{CH}_{2}\right)_{2}\left(\mathrm{CH}_{2}\right)_{2}\right], 67.52\left[\mathrm{O}\left(\mathrm{CH}_{2}\right)_{2}\left(\mathrm{CH}_{2}\right)_{2}\right], 128.25$, 129.92 and $132.49\left(\mathrm{C}_{6} \mathrm{H}_{5}\right)$.

Compound 9 . A solution of compound $8(0.01 \mathrm{~mol})$ was added dropwise to an equimolar solution of $3 \mathbf{a}$. This mixture was stirred for $12 \mathrm{~h}$, after which the solvents were removed in vacuo. Redissolving the product in hexane $\left(50 \mathrm{~cm}^{3}\right)$ and filtering off the $\mathrm{LiBr}$ afforded crystals of 9 suitable for X-ray structure determination. Yield: $3.6 \mathrm{~g}, 54 \%$. NMR (room temperature): ${ }^{1} \mathrm{H}$, $\delta \quad 0.20\left(\mathrm{~s}, \mathrm{SiMe}_{3}\right), \quad 1.42\left[\mathrm{t}, \mathrm{O}\left(\mathrm{CH}_{2}\right)_{2}\left(\mathrm{CH}_{2}\right)_{2}\right], 3.63[\mathrm{t}$, $\left.\mathrm{O}\left(\mathrm{CH}_{2}\right)_{2}\left(\mathrm{CH}_{2}\right)_{2}\right]$ and 6.99-7.94 (m, $\left.\mathrm{C}_{6} \mathrm{H}_{5}\right) ;{ }^{13} \mathrm{C}, \delta 2.39\left(\mathrm{SiMe}_{3}\right)$, $25.58\left[\mathrm{O}\left(\mathrm{CH}_{2}\right)_{2}\left(\mathrm{CH}_{2}\right)_{2}\right], 68.28\left[\mathrm{O}\left(\mathrm{CH}_{2}\right)_{2}\left(\mathrm{CH}_{2}\right)_{2}\right], 124.31$, $129.08,130.34$ and $155.91\left(\mathrm{C}_{6} \mathrm{H}_{5}\right) ;{ }^{29} \mathrm{Si}, \delta-2.6\left(\mathrm{SiMe}_{3}\right)$.

Compound 10. The compound $\mathrm{Me}_{3} \mathrm{Si}-\mathrm{N}=\mathrm{S}=\mathrm{N}-\mathrm{SiMe}_{3}(0.005$ 
Table 5 Atom coordinates $\left(\times 10^{4}\right)$

\begin{tabular}{|c|c|c|c|c|c|c|c|}
\hline Atom & $x$ & $y$ & $z$ & Atom & $x$ & $y$ & $z$ \\
\hline \multicolumn{8}{|c|}{ Compound 1a } \\
\hline $\begin{array}{l}S(1) \\
C(1) \\
C(2) \\
C(3) \\
C(4) \\
C(5) \\
C(6) \\
N(1) \\
S i(1)\end{array}$ & $\begin{array}{l}5211(1) \\
5098(2) \\
6377(2) \\
6260(2) \\
4880(2) \\
3610(2) \\
3710(2) \\
3708(1) \\
2727(1)\end{array}$ & $\begin{array}{r}2526(1) \\
2271(1) \\
1212(2) \\
911(2) \\
1653(2) \\
2699(2) \\
3003(2) \\
3992(1) \\
4044(1)\end{array}$ & $\begin{array}{l}6293(1) \\
4718(1) \\
4159(2) \\
3005(2) \\
2424(2) \\
2991(2) \\
4153(1) \\
6465(1) \\
8075(1)\end{array}$ & $\begin{array}{l}C(7) \\
C(8) \\
C(9) \\
N(2) \\
S i(2) \\
C(10) \\
C(11) \\
C(12)\end{array}$ & $\begin{array}{r}3390(2) \\
633(2) \\
2897(2) \\
6813(1) \\
8339(1) \\
7742(2) \\
9043(2) \\
9893(2)\end{array}$ & $\begin{array}{l}5029(2) \\
5222(2) \\
2034(2) \\
2958(1) \\
1975(1) \\
2288(2) \\
-184(2) \\
2770(2)\end{array}$ & $\begin{array}{l}8897(2) \\
7852(2) \\
9251(2) \\
5845(1) \\
6858(1) \\
8580(2) \\
7081(2) \\
5897(2)\end{array}$ \\
\hline \multicolumn{8}{|c|}{ Compound $2 c$} \\
\hline $\begin{array}{l}S(1) \\
C(1) \\
C(14) \\
C(15) \\
C(16) \\
N(1) \\
S i(1) \\
C(11) \\
C(12)\end{array}$ & $\begin{array}{l}5602(1) \\
3674(2) \\
3681(2) \\
2472(2) \\
3465(2) \\
5474(1) \\
6629(1) \\
8610(2) \\
6661(2)\end{array}$ & $\begin{array}{l}4194(1) \\
3617(1) \\
2133(1) \\
4283(2) \\
3961(2) \\
5771(1) \\
6664(1) \\
5995(2) \\
8375(2)\end{array}$ & $\begin{array}{l}3671(1) \\
3355(1) \\
3466(1) \\
3761(1) \\
2573(1) \\
3649(1) \\
3141(1) \\
3 \quad 187(1) \\
3502(1)\end{array}$ & $\begin{array}{l}C(13) \\
N(2) \\
C(2) \\
C(21) \\
C(22) \\
C(23) \\
C(24) \\
C(25) \\
L i(1)\end{array}$ & $\begin{array}{l}5946(2) \\
5754(1) \\
6916(2) \\
6515(2) \\
7690(2) \\
9283(2) \\
9703(2) \\
8528(2) \\
5537(3)\end{array}$ & $\begin{array}{r}6761(2) \\
3820(1) \\
2771(1) \\
1946(1) \\
861(1) \\
1426(2) \\
2242(2) \\
3322(1) \\
5915(2)\end{array}$ & $\begin{array}{l}2186(1) \\
4512(1) \\
4651(1) \\
5283(1) \\
5451(1) \\
5573(1) \\
4943(1) \\
4772(1) \\
4686(1)\end{array}$ \\
\hline \multicolumn{8}{|c|}{ Compound 3c } \\
\hline $\begin{array}{l}S(1) \\
C(1) \\
C(2) \\
C(3) \\
C(4) \\
C(5) \\
C(6) \\
N(1) \\
S i(1) \\
C(11) \\
C(12) \\
C(13)\end{array}$ & $\begin{array}{l}4766(1) \\
3947(1) \\
4076(1) \\
3456(1) \\
2718(1) \\
2592(1) \\
3209(1) \\
4418(1) \\
4211(1) \\
3872(1) \\
3441(2) \\
5080(2)\end{array}$ & $\begin{array}{l}5594(1) \\
4725(2) \\
3810(2) \\
3153(2) \\
3404(2) \\
4301(2) \\
4980(2) \\
6520(1) \\
7729(1) \\
8530(2) \\
7694(2) \\
8367(2)\end{array}$ & $\begin{array}{l}5997(1) \\
5451(1) \\
5124(1) \\
4654(1) \\
4520(1) \\
4856(1) \\
5320(1) \\
6321(1) \\
5865(1) \\
6490(2) \\
4752(2) \\
5868(2)\end{array}$ & $\begin{array}{l}\mathrm{N}(2) \\
\mathrm{C}(20) \\
\mathrm{C}(21) \\
\mathrm{C}(22) \\
\mathrm{C}(23) \\
\mathrm{C}(24) \\
\mathrm{C}(25) \\
\mathrm{Li}(1) \\
\mathrm{Li}(2) \\
\mathrm{O} \\
\mathrm{C}(7) \\
\mathrm{C}(8)\end{array}$ & $\begin{array}{l}5326(1) \\
6144(1) \\
6549(1) \\
7399(1) \\
7844(1) \\
7458(1) \\
6602(1) \\
5000 \\
5000 \\
5000 \\
4522(1) \\
4967(2)\end{array}$ & $\begin{array}{l}4893(1) \\
4856(2) \\
3914(2) \\
3834(2) \\
4823(2) \\
5779(2) \\
5857(2) \\
6064(4) \\
4004(4) \\
2483(2) \\
1878(2) \\
1341(3)\end{array}$ & $\begin{array}{l}6806(1) \\
6944(1) \\
7482(1) \\
7674(1) \\
8085(2) \\
7550(2) \\
7350(1) \\
7500 \\
7500 \\
7500 \\
6772(1) \\
6408(2)\end{array}$ \\
\hline \multicolumn{8}{|c|}{ Compound $\mathbf{4 b}$} \\
\hline $\begin{array}{l}\mathrm{Na} \\
\mathrm{Li} \\
\mathrm{S}(1) \\
\mathrm{C}(1) \\
\mathrm{C}(2) \\
\mathrm{C}(3) \\
\mathrm{C}(4) \\
\mathrm{C}(5) \\
\mathrm{C}(6) \\
\mathrm{N}(1) \\
\mathrm{Si}(1)\end{array}$ & $\begin{array}{l}5000 \\
5000 \\
3896(1) \\
4598(2) \\
3868(2) \\
4369(2) \\
5595(2) \\
6326(2) \\
5823(2) \\
4937(2) \\
5121(1)\end{array}$ & $\begin{array}{l}6381(1) \\
7930(2) \\
7794(1) \\
7265(1) \\
6982(1) \\
6581(1) \\
6448(1) \\
6734(1) \\
7150(1) \\
8316(1) \\
9107(1)\end{array}$ & $\begin{array}{l}2500 \\
2500 \\
3707(1) \\
4375(1) \\
4887(1) \\
5407(1) \\
5406(1) \\
4896(1) \\
4384(1) \\
3462(1) \\
3862(1)\end{array}$ & $\begin{array}{l}C(11) \\
C(12) \\
C(13) \\
N(2) \\
\operatorname{Si}(2) \\
C(21) \\
C(22) \\
C(23) \\
O(1) \\
C(7) \\
C(8)\end{array}$ & $\begin{array}{l}5704(3) \\
6245(3) \\
3694(2) \\
3766(1) \\
2313(1) \\
1223(2) \\
2407(2) \\
1734(2) \\
4568(2) \\
4554(3) \\
5088(2)\end{array}$ & $\begin{array}{l}8994(1) \\
9600(1) \\
9621(1) \\
7248(1) \\
7113(1) \\
6856(1) \\
6373(1) \\
7908(1) \\
5369(1) \\
5374(1) \\
4748(1)\end{array}$ & 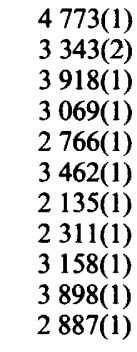 \\
\hline \multicolumn{8}{|c|}{ Compound 5b } \\
\hline $\begin{array}{l}K(1) \\
S(1) \\
C(1) \\
C(2) \\
C(3) \\
C(4) \\
C(5) \\
C(6) \\
N(1) \\
S i(1) \\
C(11) \\
C(12)\end{array}$ & $\begin{array}{r}-447(1) \\
-1821(1) \\
-2548(2) \\
-2129(2) \\
-2711(2) \\
-3707(2) \\
-4133(2) \\
-3559(2) \\
-2408(1) \\
-3408(1) \\
-2672(2) \\
-3695(2)\end{array}$ & $\begin{array}{r}11059(1) \\
9543(1) \\
9014(1) \\
8303(1) \\
7883(1) \\
8162(1) \\
8860(1) \\
9283(1) \\
10331(1) \\
10701(1) \\
10702(1) \\
11656(1)\end{array}$ & $\begin{array}{r}-625(1) \\
-2027(1) \\
-1049(1) \\
-841(2) \\
-127(2) \\
375(2) \\
155(2) \\
-563(2) \\
-1897(1) \\
-2978(1) \\
-4259(2) \\
-2592(2)\end{array}$ & $\begin{array}{l}C(13) \\
N(2) \\
S i(2) \\
C(21) \\
C(22) \\
C(23) \\
C(7) \\
O(1) \\
C(8) \\
C(9) \\
O(2) \\
C(10)\end{array}$ & $\begin{array}{r}-5029(2) \\
-303(1) \\
840(1) \\
2411(2) \\
409(2) \\
1171(2) \\
-2016(3) \\
-1116(2) \\
-1395(2) \\
-357(2) \\
-307(1) \\
549(3)\end{array}$ & $\begin{array}{r}10235(1) \\
9519(1) \\
9404(1) \\
9168(1) \\
8680(1) \\
10239(1) \\
12801(2) \\
12673(1) \\
13118(1) \\
13042(1) \\
12324(1) \\
12268(1)\end{array}$ & $\begin{array}{r}-3288(2) \\
-1485(1) \\
-2331(1) \\
-1446(2) \\
-3375(2) \\
-3087(2) \\
764(2) \\
37(1) \\
-897(2) \\
-1580(2) \\
-1961(1) \\
-2748(2)\end{array}$ \\
\hline \multicolumn{8}{|c|}{ Compound 8} \\
\hline $\begin{array}{l}S(1) \\
C(1) \\
C(2) \\
C(3) \\
C(4) \\
C(5) \\
C(6) \\
N(1) \\
\text { Si(1) } \\
C(11) \\
C(12) \\
C(13)\end{array}$ & $\begin{array}{l}2292(1) \\
3988(3) \\
4149(3) \\
5452(4) \\
6586(3) \\
6426(3) \\
5125(3) \\
1316(2) \\
1397(1) \\
2475(4) \\
2193(4) \\
-375(4)\end{array}$ & $\begin{array}{l}4324(1) \\
3767(3) \\
3793(5) \\
3346(5) \\
2908(4) \\
2894(4) \\
3327(3) \\
5881(3) \\
7439(1) \\
7856(4) \\
7228(4) \\
8956(4)\end{array}$ & $\begin{array}{l}8335(1) \\
7839(2) \\
6704(3) \\
6366(3) \\
7139(3) \\
8270(3) \\
8626(3) \\
7381(2) \\
7320(1) \\
6181(3) \\
8770(3) \\
6901(4)\end{array}$ & $\begin{array}{l}\mathrm{N}(2) \\
\mathrm{Si}(2) \\
\mathrm{C}(21) \\
\mathrm{C}(22) \\
\mathrm{C}(23) \\
\mathrm{Mg}(1) \\
\mathrm{Br}(1) \\
\mathrm{O}(1) \\
\mathrm{C}(7) \\
\mathrm{C}(8) \\
\mathrm{C}(9) \\
\mathrm{C}(10)\end{array}$ & $\begin{array}{r}1660(2) \\
2161(1) \\
585(3) \\
3330(3) \\
3074(3) \\
302(1) \\
267(1) \\
-1655(2) \\
-2892(4) \\
-3918(4) \\
-3552(4) \\
-2034(4)\end{array}$ & $\begin{array}{r}3393(2) \\
1600(1) \\
1322(4) \\
448(4) \\
1077(4) \\
5100(1) \\
6586(1) \\
6120(3) \\
7067(6) \\
7826(7) \\
6656(6) \\
5876(6)\end{array}$ & $\begin{array}{r}7963(2) \\
8747(1) \\
8915(3) \\
7934(3) \\
10244(3) \\
6517(1) \\
4377(1) \\
6849(2) \\
6003(4) \\
6680(6) \\
7920(5) \\
8029(4)\end{array}$ \\
\hline
\end{tabular}


Table 5 (continued)

\begin{tabular}{|c|c|c|c|c|c|c|c|}
\hline Atom & $x$ & $y$ & $z$ & Atom & $x$ & $y$ & $z$ \\
\hline \multicolumn{8}{|c|}{ Compound 9} \\
\hline$S(1)$ & $4348(1)$ & $8390(1)$ & $5784(1)$ & $\mathrm{C}(63)$ & $5519(3)$ & $5425(2)$ & $6915(2)$ \\
\hline$C(51)$ & $5483(3)$ & $7885(2)$ & $5362(1)$ & $C(64)$ & $5475(3)$ & $4681(2)$ & $6860(2)$ \\
\hline$C(52)$ & $5594(3)$ & $7140(2)$ & $5406(2)$ & $C(65)$ & $4346(3)$ & $4334(2)$ & $6609(2)$ \\
\hline$C(53)$ & $6451(3)$ & $6788(2)$ & $5049(2)$ & $\mathrm{C}(66)$ & $3242(3)$ & $4737(2)$ & $6402(1)$ \\
\hline C(54) & $7178(3)$ & $7173(2)$ & $4656(2)$ & $N(3)$ & $1752(2)$ & $6620(1)$ & $6688(1)$ \\
\hline C (55) & $7088(3)$ & $7915(2)$ & $4620(2)$ & $\mathrm{Si}(3)$ & $942(1)$ & $6419(1)$ & $7359(1)$ \\
\hline$C(56)$ & $6239(3)$ & $8274(2)$ & $4975(2)$ & $C(31)$ & $664(3)$ & $7281(2)$ & $7802(1)$ \\
\hline $\mathrm{N}(1)$ & $2971(2)$ & $8247(1)$ & $5332(1)$ & $C(32)$ & $-653(3)$ & $5978(2)$ & $7070(2)$ \\
\hline $\mathrm{Si}(1)$ & $2362(1)$ & $8873(1)$ & $4728(1)$ & $C(33)$ & $1907(3)$ & $5794(2)$ & $7974(2)$ \\
\hline $\mathrm{C}(11)$ & $3185(3)$ & $8866(2)$ & $3961(2)$ & $\mathrm{N}(4)$ & $2272(2)$ & $6475(1)$ & $5528(1)$ \\
\hline$C(12)$ & 621(3) & $8652(2)$ & $4473(2)$ & $\mathrm{Si}(4)$ & $2035(1)$ & $6126(1)$ & $4720(1)$ \\
\hline $\mathrm{C}(13)$ & $2514(4)$ & $9825(2)$ & $5064(2)$ & $C(41)$ & $2706(3)$ & $6780(2)$ & $4158(2)$ \\
\hline$N(2)$ & $4171(2)$ & $7916(1)$ & $6443(1)$ & $C(42)$ & $276(3)$ & $5986(2)$ & $4423(2)$ \\
\hline $\mathrm{Si}(2)$ & $5188(1)$ & $8047(1)$ & 7 192(1) & $C(43)$ & $2836(4)$ & $5231(2)$ & $4671(2)$ \\
\hline $\mathrm{C}(21)$ & $6696(3)$ & $7499(2)$ & $7222(2)$ & $\mathrm{Mg}$ & $2377(1)$ & $7467(1)$ & $6052(1)$ \\
\hline $\mathrm{C}(22)$ & $5645(3)$ & $9018(2)$ & $7314(2)$ & $\mathrm{O}$ & $962(2)$ & $8170(1)$ & $6293(1)$ \\
\hline $\mathrm{C}(23)$ & $4281(3)$ & $7744(2)$ & $7873(2)$ & $C(71)$ & $1249(3)$ & $8887(2)$ & $6577(2)$ \\
\hline$S(2)$ & $1844(1)$ & $5994(1)$ & $6134(1)$ & $C(72)$ & 23(3) & $9311(2)$ & $6398(2)$ \\
\hline $\mathrm{C}(61)$ & $3287(3)$ & $5486(2)$ & $6446(1)$ & $\mathrm{C}(73)$ & $-1005(3)$ & $8735(2)$ & $6437(2)$ \\
\hline $\mathrm{C}(62)$ & $4423(3)$ & $5830(2)$ & $6710(2)$ & $C(74)$ & $-427(3)$ & $8072(2)$ & $6151(2)$ \\
\hline \multicolumn{8}{|c|}{ Compound 10} \\
\hline $\mathrm{Cu}(1)$ & $6554(1)$ & $4445(1)$ & $4717(1)$ & $\mathrm{Si}(1)$ & $7301(1)$ & $6086(1)$ & $1782(1)$ \\
\hline$S(1)$ & $4658(1)$ & $7743(1)$ & $3521(1)$ & $\mathrm{C}(11)$ & $7105(3)$ & $8001(3)$ & $729(3)$ \\
\hline $\mathrm{C}(1)$ & $4866(3)$ & $7964(3)$ & $5115(2)$ & $\mathrm{C}(12)$ & $9360(3)$ & $4817(3)$ & $2157(3)$ \\
\hline $\mathrm{C}(2)$ & $3557(3)$ & $8599(3)$ & $5963(3)$ & $\mathrm{C}(13)$ & $6705(3)$ & $5162(3)$ & 854(3) \\
\hline $\mathrm{C}(3)$ & $3717(3)$ & $8802(3)$ & $7167(3)$ & $N(2)$ & $3184(2)$ & $7337(2)$ & $3917(2)$ \\
\hline $\mathrm{C}(4)$ & $5156(3)$ & $8384(3)$ & $7527(3)$ & $\mathrm{Si}(2)$ & $1650(1)$ & $8328(1)$ & $2897(1)$ \\
\hline$C(5)$ & $6457(3)$ & $7768(3)$ & $6670(3)$ & $\mathrm{C}(21)$ & $756(3)$ & $10416(3)$ & $2817(3)$ \\
\hline$C(6)$ & $6314(3)$ & $7561(3)$ & $5466(3)$ & $\mathrm{C}(22)$ & $2234(4)$ & $8093(4)$ & $1123(3)$ \\
\hline $\mathrm{N}(1)$ & $6242(2)$ & $6236(2)$ & $3351(2)$ & $C(23)$ & $228(3)$ & $7533(3)$ & $3719(3)$ \\
\hline
\end{tabular}

mol) was dissolved in hexane $\left(20 \mathrm{~cm}^{3}\right)$ and cooled to $-30^{\circ} \mathrm{C}$. To this solution anhydrous $\mathrm{CuCl}(0.005 \mathrm{~mol})$ was added followed by $0.005 \mathrm{~mol} \mathrm{LiPh}\left(2 \mathrm{~mol} \mathrm{dm}^{-3}\right.$ solution in hexane$\left.\mathrm{Et}_{2} \mathrm{O}\right)$ dropwise. After warming to room temperature, the reaction mixture was refluxed for $2 \mathrm{~h}$. After cooling the $\mathrm{LiCl}$ was filtered off. Crystals of compound 10 were obtained by allowing the solution to stand for $12 \mathrm{~h}$. Yield: $1.3 \mathrm{~g}, 74^{\circ} \%$. M.p. $141^{\circ} \mathrm{C}$ (decomp.). NMR (room temperature): ${ }^{1} \mathrm{H}, \delta 0.21$ (s, $\mathrm{SiMe}_{3}$ ) and 7.00-7.95 (m, $\left.\mathrm{C}_{6} \mathrm{H}_{5}\right) ;{ }^{13} \mathrm{C}, \delta 2.72\left[\mathrm{Si}\left(\mathrm{CH}_{3}\right)_{3}\right], 126.20,128.41$, 128.57 and $156.10\left(\mathrm{C}_{6} \mathrm{H}_{5}\right) ;{ }^{29} \mathrm{Si}, \delta 5.1\left(\mathrm{SiMe}_{3}\right)$. Mass spectra: (electron impact) $m / z 694$ (18), 617 (100); (field ionization) $694(100 \%)$. IR: 2949vs, $1472 \mathrm{~m}, 1442 \mathrm{~m}, 1260 \mathrm{~s}, 1249 \mathrm{vs}$, $1095 \mathrm{~m}, 988 \mathrm{vs}, 964 \mathrm{vs}, 866 \mathrm{vs}, 833 \mathrm{vs}, 745 \mathrm{vs}, 684 \mathrm{~s}, 452 \mathrm{~m}$ and $321 \mathrm{~m} \mathrm{~cm}^{-1}$.

Crystal Structure Determinations of Compounds 1a, $2 \mathbf{c}, \mathbf{3 c}, \mathbf{4 b}$, 5b and 8-10.-Data were collected on a Stoe-Siemens AED diffractometer using graphite-monochromated Mo-K $\alpha$ radiation $(\lambda=71.073 \mathrm{pm})$. The structures of compounds 8 and 10 were solved by the Patterson method, those of $1 \mathrm{a}, 2 \mathrm{c}, \mathbf{3 c}, \mathbf{4 b}, \mathbf{5 b}$ and 9 by direct methods. ${ }^{32}$ They were refined by full-matrix least-squares techniques. ${ }^{33}$ All non-hydrogen atoms were refined anisotropically. Hydrogen atoms were included in calculated positions. A semiempirical absorption correction was applied for 8 and 10. A weighting scheme $w^{-1}=\sigma^{2}(F)+g F^{2}$ was employed.

Additional material available from the Cambridge Crystallographic Data Centre comprises H-atom coordinates, thermal parameters and remaining bond lengths and angles.

\section{Acknowledgements}

We thank the Deutsche Forschungsgemeinschaft and the Fonds der Deutschen Industrie for financial support and Dr. G. Elter and Mr. W. Zolke for recording the ${ }^{7} \mathrm{Li}$ MAS NMR spectra.

\section{References}

1 U. Wannagat and H. Kuckertz, Angew. Chem., 1962, 74, 117. 2 O. J. Scherer and R. Schmitt, J. Organomet. Chem., 1969, 16, P11. 3 J. Kuyper and K. Vrieze, J. Chem. Soc., Chem. Commun., 1976, 64.

4 J. Kuyper, P. C. Keijzer and K. Vrieze, J. Organomet. Chem., 1976, $116,1$.

5 O. Scherer and R. Wies, Z. Naturforsch., Teil B, 1970, 25, 1486. 6 F. Pauer and D. Stalke, J. Organomet. Chem., 1991, 418, 127.

7 F. Pauer, J. Rocha and D. Stalke, J. Chem. Soc., Chem. Commun., 1991, 1477.

8 E. Eaborn, P. B. Hitchcock, J. D. Smith and A. C. Sullivan, J. Chem. Soc., Chem. Commun., 1983, 827.

9 F. T. Edelmann, F. Knösel, F. Pauer, D. Stalke and W. Bauer, $J$. Organomet. Chem., 1992, 438, 1.

10 D. G. Anderson, H. E. Robertson, D. W. H. Rankin and J. D. Woollins, J. Chem. Soc., Dalton Trans., 1989, 859.

11 M. Rock, P. Bravin and K. Seppelt, Z. Anorg. Allg. Chem., 1992, 618, 89.

12 K. Gregory, P. v. R. Schleyer and R. Snaith, Adv. Inorg. Chem., 1991, $37,47$.

13 E. Weiss, G. Sauermann and G. Thirase, Chem. Ber., 1983, 116, 74.

14 W. Clegg, R. E. Mulvey, R. Snaith, G. E. Toogood and K. Wade, J. Chem. Soc., Chem. Commun., 1986, 1740.

15 U. Schümann and E. Weiss, Angew. Chem., 1988, 100, 573; Angew. Chem., Int. Ed. Engl., 1988, 27, 584.

16 D. Barr, W. Clegg, R. E. Mulvey and R. Snaith, J. Chem. Soc., Chem. Commun., 1989, 57.

17 G. Boche, H. Etzrod, W. Massa and G. Baum, Angew. Chem., 1985, 97, 858; Angew. Chem., Int. Ed. Engl., 1985, 24, 863.

18 M. Veith and J. Böhnlein, Chem. Ber., 1989, 122, 603.

19 D. Stalke, M. Wedler and F. T. Edelmann, J. Organomet. Chem., 1992, 431, C1.

20 A. L. Spek, P. Voorbergen, G. Schat, C. Blomberg and F. Bickelhaupt, J. Organomet. Chem., 1974, 77, 147.

21 K. Prout and R. A. Forder, Acta Crystallogr., Sect. B, 1967, 31, 852.

22 M. Veith and R. Rösler, J. Organomet. Chem., 1982, 229, 131. 
23 M. Veith, W. Frank, F. Töllner and H. Lange, J. Organomet. Chem., $1987,326,315$.

24 M. Veith, J. Böhnlein and V. Huch, Chem. Ber., 1989, 122, 841.

25 S. Maier, W. Hiller, J. Strähle, C. Ergezinger and K. Dehnicke, $Z$. Naturforsch., Teil B, 1988, 43, 1628.

26 A. Heine and D. Stalke, Angew. Chem., 1993, 105, 90; Angew. Chem., Int. Ed. Engl., 1993, 32, 121.

27 A. Samoson and E. Lippmaa, J. Magn. Reson., 1988, 78, 255.
28 A. Steiner and D. Stalke, Inorg. Chem., 1993, 32, 1977.

29 D. Klamann, C. Sass and M. Zelenka, Chem. Ber., 1959, 92, 1910. 30 I. Ruppert, V. Bastian and R. Appel, Chem. Ber., 1975, 108, 2329.

31 F. Pauer, Dissertation, University of Göttingen, 1991.

32 G. M. Sheldrick, Acta Crystallogr., Sect. A, 1990, 46, 467.

33 SHELXTL PLUS, G. M. Sheldrick, University of Göttingen, 1986.

Received 9th August 1993; Paper 3/04813F 